\title{
Cavanaugh: A Late Prehistoric Platform Mound in Western Arkansas
}

Gregory Vogel

University of Arkansas

Follow this and additional works at: https://scholarworks.sfasu.edu/ita

Part of the American Material Culture Commons, Archaeological Anthropology Commons, Environmental Studies Commons, Other American Studies Commons, Other Arts and Humanities Commons, Other History of Art, Architecture, and Archaeology Commons, and the United States History Commons

Tell us how this article helped you.

This Article is brought to you for free and open access by the Center for Regional Heritage Research at SFA ScholarWorks. It has been accepted for inclusion in Index of Texas Archaeology: Open Access Gray Literature from the Lone Star State by an authorized editor of SFA ScholarWorks. For more information, please contact cdsscholarworks@sfasu.edu. 


\section{Cavanaugh: A Late Prehistoric Platform Mound in Western Arkansas}

Creative Commons License

(c) (i) (8)

This work is licensed under a Creative Commons Attribution-NonCommercial 4.0 International License 


\title{
Cavanaugh: A Late Prehistoric Platform Mound in Western Arkansas
}

\author{
Gregory Vogel \\ The University of Arkansas
}

\section{Introduction}

Cavanaugh Mound (3SB3, also known as Etter's Mound, Jones Mound [Newkumet 1940], Site Zeta [Dollar 1958], and occasionally misspelled Cavenaugh) is a largely intact Late Prehistoric platform mound on the Arkansas River just east of the Oklahoma border, about $14 \mathrm{~km}$ from the Spiro Mounds complex (Figure 1). The site is situated on a high terrace above the Arkansas River as it runs between the Ouachita Mountains to the south and the Ozarks to the north. The Poteau River enters the Arkansas River floodplain just west of Cavanaugh, creating one of the widest stretches of bottomland in the region. The area immediately around Cavanaugh Mound is now a residential neighborhood in the city of Fort Smith, and the mound itself is in a tiny lot with a church to the south, a trailer park to the east (named Indian Mounds Trailer Park), and a row of houses to the west. At about $60 \mathrm{~m}$ across and $9 \mathrm{~m}$ high, Cavanaugh Mound is one of the largest, if not the largest, prehistoric mound in the region. Very little has been published concerning this site, however, and very little formal archeological work has been done there.

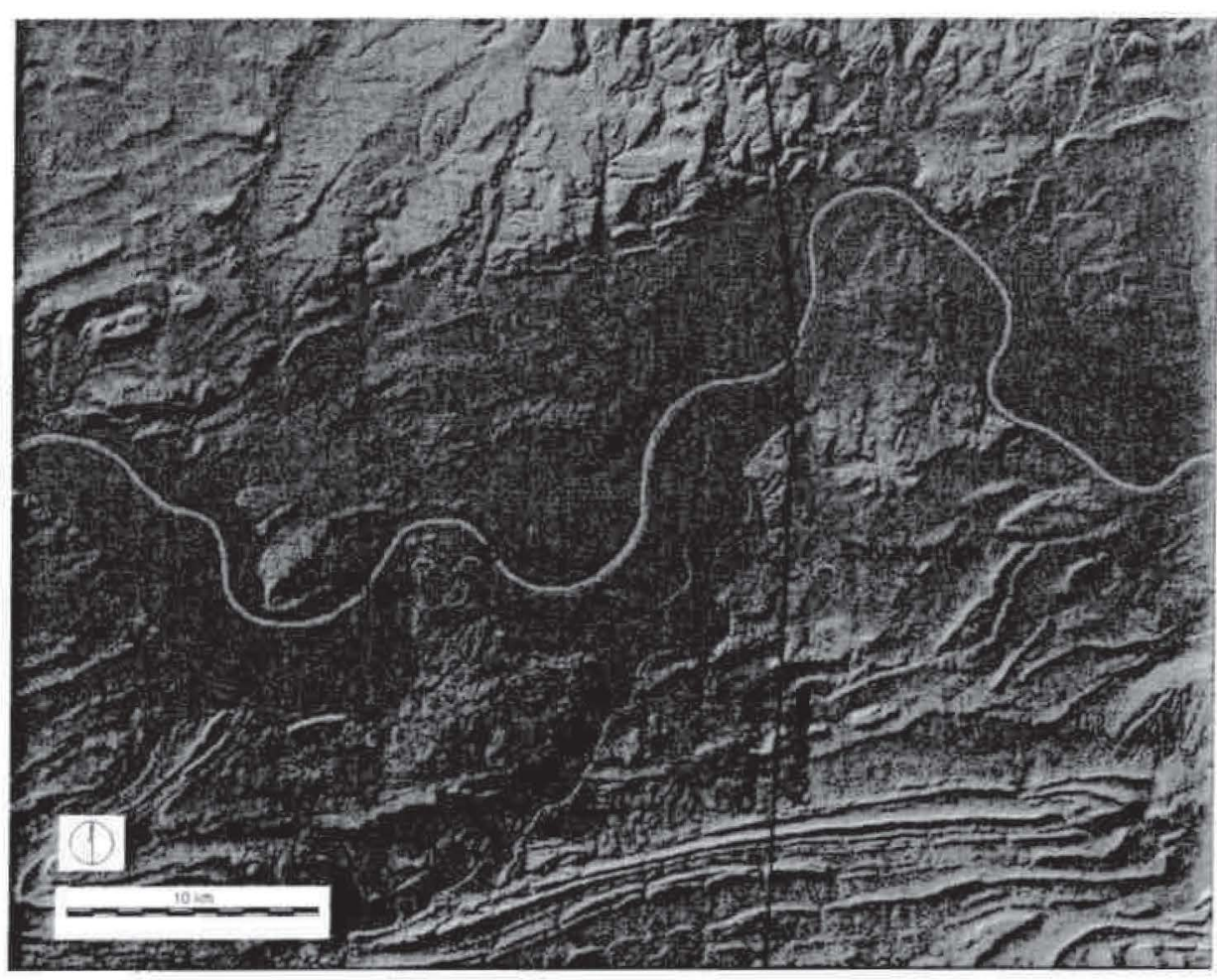

Figure 1. Shaded relief map of the region surrounding Cavanaugh Mound.
This article is partly intended to call attention to Cavanaugh Mound, and to compile all reports and descriptions of the mound in one publication. The first part of the article is therefore mostly descriptive. I also offer some tentative interpretations of the site and its possible relationship to the nearby Spiro and Skidgel sites. The size, shape, and stratigraphy of the mound all indicate that it was constructed and used in a manner similar to other Caddoan era platform mounds in the Arkansas River valley. The mound 
appears to be alone on the landscape, not connected to a group of surrounding mounds and not located within or near a contemporaneous settlement. It overlooks the Poteau/Arkansas River bottoms to the west and was probably visible from both the Spiro and Skidgel sites in prehistoric times.

\section{History of Investigations at Cavanaugh}

The first printed mention of Cavanaugh probably comes from Goodspeed's History of Arkansas, first published in 1889. After a brief discussion of the "Mound Builder" question, Goodspeed (1889:687) relates, "There are some earth formations in Sebastian County supposed by some to have been made by the Mound Builders, but so far as they have been explored nothing of interest leading to a certainty of whether they were formed by nature or by man has been found." No other earthworks are reported for Sebastian County, but there are numerous naturally-formed prairie mounds that have occasionally been mistaken for prehistoric constructions. If this brief passage does relate to the Cavanaugh Mound it is the first time the site is mentioned in print. There does not appear to be further mention of the site for several decades after this.

The first systematic observations of Cavanaugh Mound come from Phil Newkumet, who visited the site in 1940 in conjunction with WPA work at the Spiro site (summarized in Brown 1996:176-179). Newkumet made a sketch of the mound at this time (Figure 2, from Brown 1996:178 and Figure 1-57) that shows it as a truncated pyramid, $61 \mathrm{~m}$ ( 200 feet) on each side, and $12 \mathrm{~m}$ ( $40 \mathrm{feet}$ ) tall. The flat summit portion of the mound is shown as square and $23 \mathrm{~m}$ (75 feet) on a side. The sketch includes a tunnel going into the mound from near the base of the east side. A cemetery is shown in the northeast quarter of the upper, flat portion. A narrow terrace or bench-like feature is shown encircling the base of the mound. No dimensions are given for this bench, but from the sketch it appears to be about $2 \mathrm{~m}$ high.

The next observations come from James Shaeffer of the Oklahoma Anthropological Society, who visited the site in October 1956 in conjunction with visits to other area sites in threat of destruction. Shaeffer's (1956:4) description reads:

Traveling farther south and east the Spiro mounds were visited under the guidance of Mr. and Mrs. Cecil Cleavanger [sic: should be Cleavenger] of Fort Smith, Arkansas. Following this a visit was made at a large mound south of Fort Smith on the property of Mr. Dale Brown, a displaced Oklahoman. This is a very well preserved and interesting mound about 30 feet high and perhaps 100 feet in diameter. There are no indications of settlements in the area and no points, pottery sherds or other debris have been seen in the vicinity. The mound itself appears to be flat topped and truncated. There are a number of white graves of the middle 1800 's on top and near the base a tunnel about four feet in diameter has been cut

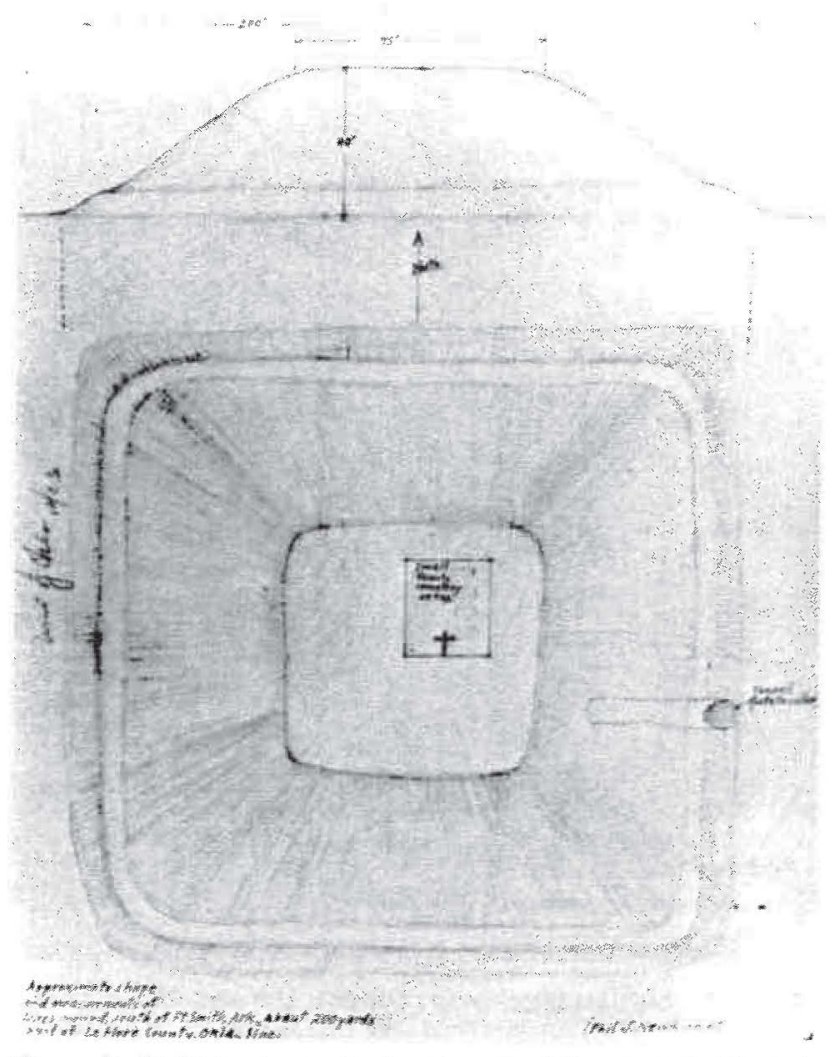

Figure 2. Phil Newkumet's sketch map of Cavanaugh Mound, made in 1940 (from Brown 1996:178 and Figure 1-57). 
almost to the center of the mound. Examination of the interior shows alternate banks of dark earth and a light grey clay mixed with large grains of burned clay. The bands are from 4 to 8 inches in width. It is estimated that there must be approximately a hundred layers or so within the mound. These facts seem to indicate a temple mound which is probably late in time.

The next observations of the site come in the form of letters from Hugh C. Rogers of Fort Smith. Rogers was a long-time amateur archeologist and a member of the Ft. Smith chapter of an archeological society. Rogers sent a letter about Cavanaugh Mound to Robert Bell dated February 15, 1958 (Bell 1980), and one to Charles McGimsey dated February 22, 1958 (Rogers 1958). Both letters are substantially similar in their descriptions of Cavanaugh. The letter to McGimsey is slightly more detailed and contains background information on Rogers and his archeological interests, including the Spiro site. The entire letter is reproduced here; the material directly concerning Cavanaugh begins with paragraph seven (There is a large mound...).

\section{Dear Dr. McGimsey:-}

We were glad that you could be with our Ft. Smith Chapter last Tuesday night and that we could get acquainted with you. I hope that we can work very closely with you and that we can get better acquainted as time goes on.

I have been an amateur archaeologist for over fifty years, first getting interested while in Vernon County, Mo. then in Lafayette County Missouri, where I was County Engineer for 29 years, and then as Supervisory Engineer at Camp (now Fort) Chaffee, for the past 15 years. I am now retired and hope, health permitting, to get interested in some Archaeological work here.

I am inclosing you a copy of my recent book, "Indian Relics and their Story" [Rogers 1954], and while it is not written in a technical manner, you might find something of interest in it. It has generally been received favorably by the public, and I have had some nice letters regarding it, and recently received an order from a man who stated that it had been recommended to him by the National Geographic Magazine. Feel free to "Pan" it if you desire.

In our meeting Tuesday, the question was brought up of "Site Preservation". I am very much interested in this, but certainly do not wish us to get a law passed that is patterned in a way after the Oklahoma Law. This law provides that there be no private excavation, even by the landowner, and that all material recovered become the property of some public museum. I feel that this law has proved unworkable, is unconstitutional in that it seeks to take private property without due process of law, and above all has been a hindrance to the actual spotting of definite source.

I have been far too busy to do much actual work during the time I have been at the Post, but have carried on a Project, to salvage as much Spiro material as possible from the old private collections in the area. I have been able to acquire a number of important Spiro artifacts, some from collections made by excavation years prior to the Commercial Excavation. I still have some relics brought in to me that I am sure were recovered from the mound (digging has not stopped) but have had to turn them down as the owner, fearing the Oklahoma law, simply states that they were "plowed up in a field". I always ask, How? When? Where? and by Whom? and in the event that I cannot trace the Artifact back to Spiro, I pass it up. I am sure that I have turned down many genuine Spiro relics, and it is a shame that many of these are still being scattered over large areas outside of Oklahoma and Arkansas.

I have done some Bluff Dweller investigations in Crawford County, just North of here, and have had two papers published in the Missouri Archaeologist. These are in Volume 16, No. 2 July 1954, and Volume 19, No. 4, December 1957. The latter might interest you, since Dr. Dellinger feels that it records the first 
direct association of the bow and arrow to the Bluff Dweller Culture. He has a copy, but if neither of these issues are available to you, would be glad to send you copies.

There is a large mound just South of the City Limits of Fort Smith. It has a base about 210 feet East and West, by 160 feet North and South, is about 25 feet high, and contains about 21,000 cubic yards. The top is flat (truncated) about 70 feet square, and on it is a family cemetery containing about 16 burials. Twelve of these are marked by headstones and foot stones, and burials date from 1881 to 1895 . I have been told that this cemetery was put there by a former landowner who has Indian blood in his veins, expressly to prevent the mound from ever being disturbed. There is a clause in the transfers of the land requiring this cemetery to remain. A number of Archaeologists have looked this mound over, but like in the course of Spiro, they have considered it to be a House Mound, and have not been interested in its investigation. I looked at it five years ago and arrived at the same opinion, taking into account the truncated top and the steep sides. The angle of repose of the slopes approaches 50 degrees from the horizontal in places, and indicates a high degree of compaction.

The land on which the mound is located has recently been purchased by Mr. and Mrs. Frank Etter, who are interested in Archaeology, and they wish to investigate it, and have asked me to act as a kind of unofficial technical advisor. I have carefully examined the mound, and feel that a proper investigation might indicate some other use than as a House, or Temple Mound. About 50 years ago there was an exploratory tunnel driven into the middle of the East end, beginning about six feet above the natural ground then sloping steeply down to the natural surface, and then back about 20 feet. I am very much interested, as an Engineer in the degree [of] compaction obtained by the builders, since no caving or spalling, either of the walls or ceiling has occurred during the ensuing years, even though it has never had any shoring or bracing. I feel sure that the degree of compaction would closely approach that possible with modern construction equipment, and would be about 100 percent (Proctor). The walls do not indicate much stratification, but show lamination in about six inch layers.

One thing that influenced me to classify it as a house mound was that on the South side, near the bottom, there was a fanlike accumulation of earth which I assumed to be the remains of an old ramp. On running down rumors about this mound, I was told that about 50 or 60 years ago, there had been a tunnel driven into the South side of the mound and that a number of fine artifacts had been recovered. Mr. and Mrs. Etter have made a test excavation at this point and uncovered the plugged mouth of this tunnel, and it runs back about 25 feet, ending in a room about six feet square, and earth excavated from this tunnel was wheeled out and formed the deformation of the mound, which I had thought to be the remains of the ramp. Rumor has it that the further excavations were stopped by the landowner who feared that it would injure the cemetery.

Since the cemetery on top is on flat ground, it might be possible that the ground was leveled at the time of the construction of the cemetery, explaining the truncated appearance. Since this mound cannot be investigated in the usual manner, due to the location of the cemetery, the usual method of excavation of the mound is impossible. I have therefore recommended that an earth auger be used to sink holes down from the top, seeking to find a void which might indicate a chamber. If so, it would be practical to drift a tunnel in from the side slope.

In the event that something important turns up, will keep in touch with you.

Sincerely,

Hugh C. Rogers

P.S. Have a large collection of artifacts from all over the United States, of which less than half is shown on the plates of my book, and would be glad to have you stop in anytime and look these over. 
The only substantive difference in Rogers' letter to Bell one week earlier (Bell 1980:11) is that the northto-south length of the mound is given as 170 feet (instead of 160 feet).

Later the same year (May 1958) the site was recorded by amateur archeologist Clyde Dollar. Like Rogers, Dollar was a long-time avocational archeologist, and also worked as an engineer for Fort Chaffee. Dollar also occasionally worked for the University of Arkansas Museum under Charles McGimsey. It is unclear whether Dollar was acquainted with Rogers (who had retired from his work at Fort Chaffee at this time), but it is possible that Rogers' letter to McGimsey led to Dollar's visit. Dollar's designation for Cavanaugh Mound was "Site Zeta," and his report for the University of Arkansas. Museum is worth quoting at length (Dollar 1958):

\section{Description and Use of Site}

A large earthen mound shaped roughly in a pyramidical form with truncated top. The sides and dimensions are generally symmetrical with a plus or minus factor of 10 feet. The site presents a most interesting problem in that the dirt of which the mound is built apparently did not come from any place in the immediate area. This absence of excavation may indicate that nearby river banks could have been the source of dirt. At present, the Poteau River, the closest natural water supply outside of shallow wet weather springs, is approximately 2.5 miles away. The soil used in the construction is also notable in its complete lack of foreign material such as sticks, grass, and rocks other than small sedimentary type pebbles of $1 / 8$ " to $1 / 4$ " diameter. The soil itself is a white sand and has the appearance of being screened before use.

The probable use of this mound by its builders was for religious ceremonies or similar occasions. Intermittent excavations for the past 60 years have apparently revealed nothing of value whatsoever. It is interesting to note that this site has been known and recognized as an "Indian" mound for almost a century. The flat area on top contains a cemetery of at least 12 marked graves and an undetermined number of unmarked graves. The present existing tombstones date from 1833 to the beginning of the 20th century. The abstract for the land specifically has a condition of sale that this cemetery will not be violated or moved. At present there are trees growing from the top of the mound; estimated age of the oldest tree is approximately 50 to 60 years old.

\section{Description and Location of Artifacts}

No artifacts have ever actually been found by this observer at the site. However, other individuals have made small finds, some dubious as to relationship to the mound, and all somewhat inconclusive. Among these finds was one small potsherd, found in the southwestern quarter of the field immediately around the mound, the stone end of a war club, broken and of poor quality, and what was reputed to be a human skull, in badly mutilated condition, taken from a three foot grave at the top of the mound. Undoubtedly this latter was an unmarked settler's grave, and no other artifact was found in association with it. The disposition of these artifacts is not known, inasmuch as the individuals who found them retained possession.

\section{Previous Work and Amount of Disturbance}

This mound presents a magnificent example of what rank amateurs and "pot hunters" can do to an authentic site. Some 60 years ago, according to the best information, a tunnel measuring approximately 4" $\times 4^{\prime} \times 60^{\prime}$ was dug into the mound from the eastem face at ground level. No record exists of any material ever being taken from the tunnel and subsequently it was converted into a potato cellar. It is still in use at the present, and the compaction of the dirt is such that no shoring or beams are required on the inside.

In recent months, Mr. Frank Etter, a man who has a passing interest in archaeology and visions of much wealth, purchased the land surrounding this mound. In December, 1957, he began operations which apparently have been carried on very spasmodically and with no tangible results other than much disturbance 
to the site. He began a tunnel from the south face, middle way up. It extends for approximately 20 feet into the mound. Although he claims to have discovered a previously emptied room' (4' $\times 6^{\prime}$ ' $\times 4^{\prime}$ ), this observer was unable to find any trace of it. Mr. Etter has never displayed any material taken from his diggings.

\section{Recommendations}

It is the opinion of this observer - or rather a guess - that this site represents the work of a very ancient culture. The mounds' obvious symmetry and workmanship, coupled with its close proximity to the Spiro Mound, tend to support this guess. It is recommended that further study be given to this site and that initial excavations be undertaken, if possible, in order to establish definitely if the site is a burial mound or otherwise.

In addition to the site description, Dollar's report includes a sketch of the mound dimensions (Figure 3), four photographs from the ground (Figures 4-7), and one low altitude aerial photograph (Figure 8). These photographs represent the most detailed documentation of the mound before its shape was altered by excavation. The sketch is schematic, showing the major dimensions of the mound and compass headings from each of the four corners. The photographs appear to have been taken in the fall or early spring, with leaves mostly down and the field around the mound in close-cropped pasture. The overall shape of the mound is clearly visible as a flat-topped or truncated pyramid. The base of the mound slopes gradually into the surrounding ground, but this may be due to erosion. Tunnels into both the east and south sides of the mound are visible in Figures 6 and 7 , with a door resting above the southern tunnel. The aerial photograph shows the flat summit free of trees and brush, apparently in close-cropped grass.

Dollar visited the site again sometime in the $1960 \mathrm{~s}$, when a large portion of the mound had been removed from the southeastern quarter. Figure 9 is a photograph Dollar took at this time. The south tunnel does not appear to be open in this photograph, but the slope of the mound above it is slumping. The figure is from a color slide, but unfortunately the resolution is not clear enough to make out any mound stratigraphy that may have been exposed. The reason for the excavation of this section of the mound is unclear, but it may have been the work of land owner Frank Etter.

The next recorded visit to the site by archeologists was in 1972, when Martha Rolingson of the Arkansas Archeological Survey (AAS) visited the site with Mickey and Cecil Cleavenger. At this time they noted that the east face of the mound had been cut away,

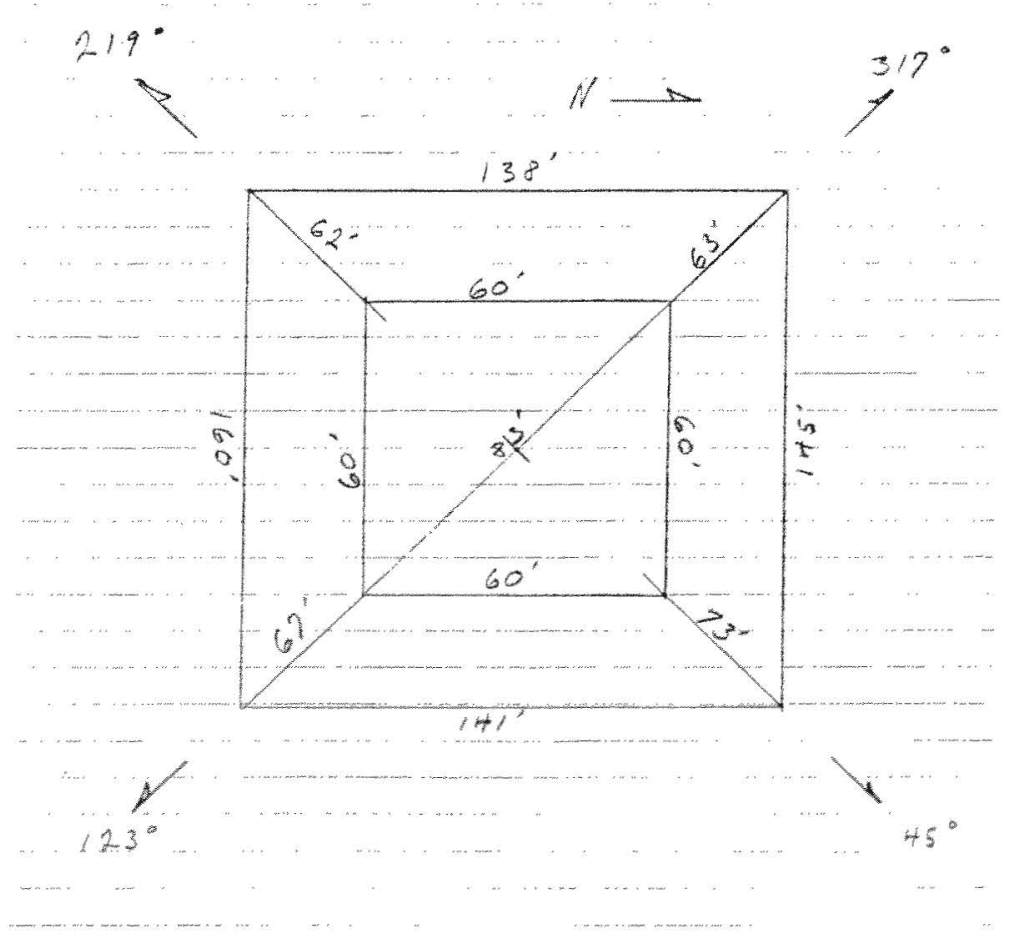

Figure 3. Clyde Dollar's sketch of the mound made in 1958 (from AAS site files for $3 \mathrm{SB} 3$ ). 


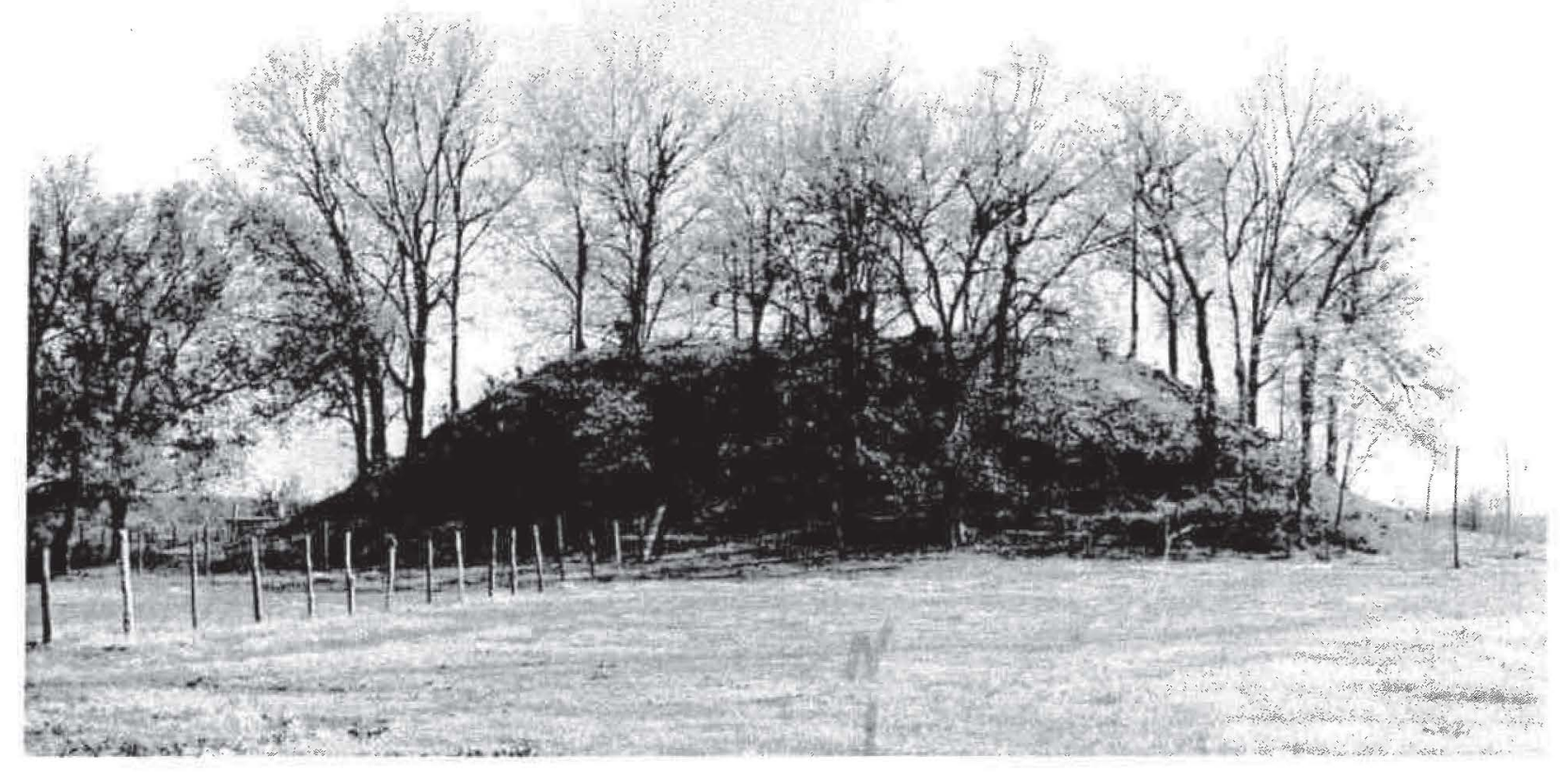

Figure 4. Clyde Dollar photograph of the mound, taken in 1958. Facing South. Photo from University of Arkansas Museum.

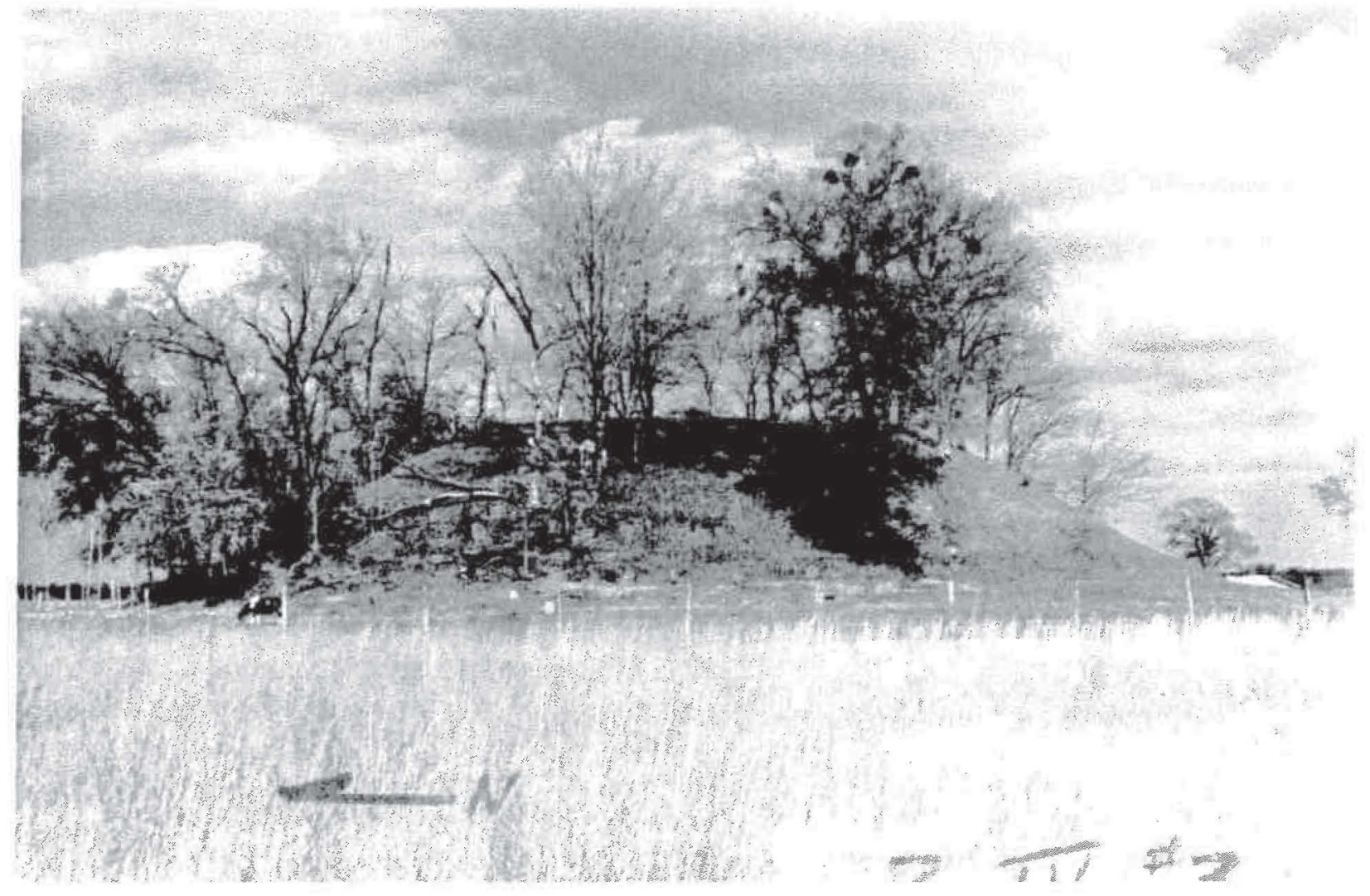

Figure 5. Clyde Dollar photograph of the mound, taken in 1958. Facing East. Photo from University of Arkansas Museum. 


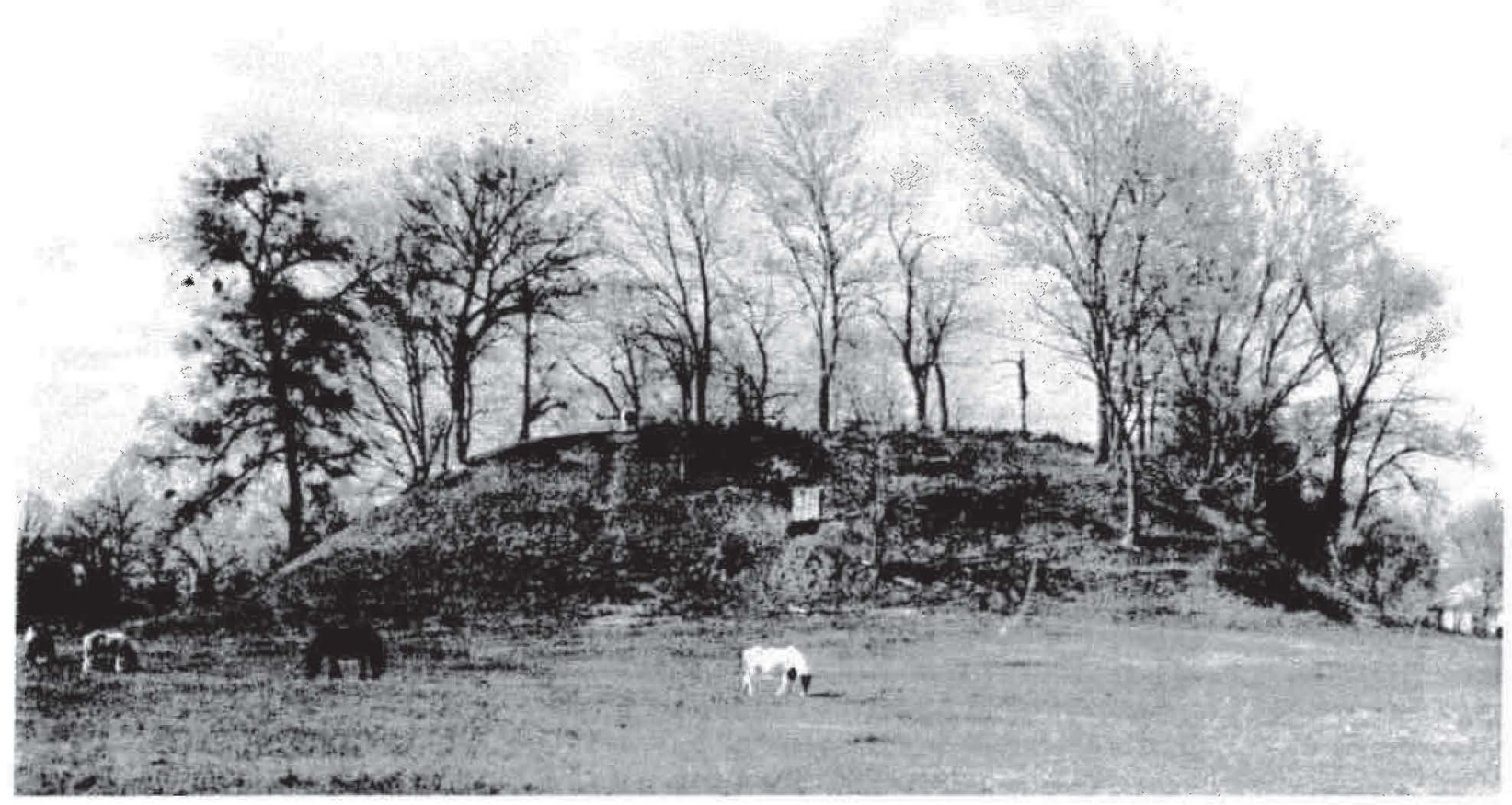

Figure 6. Clyde Dollar photograph of the mound, taken in 1958. Facing North. The southern tunnel is open, with fresh backfill accumulated beneath it. Photo from University of Arkansas Museum.

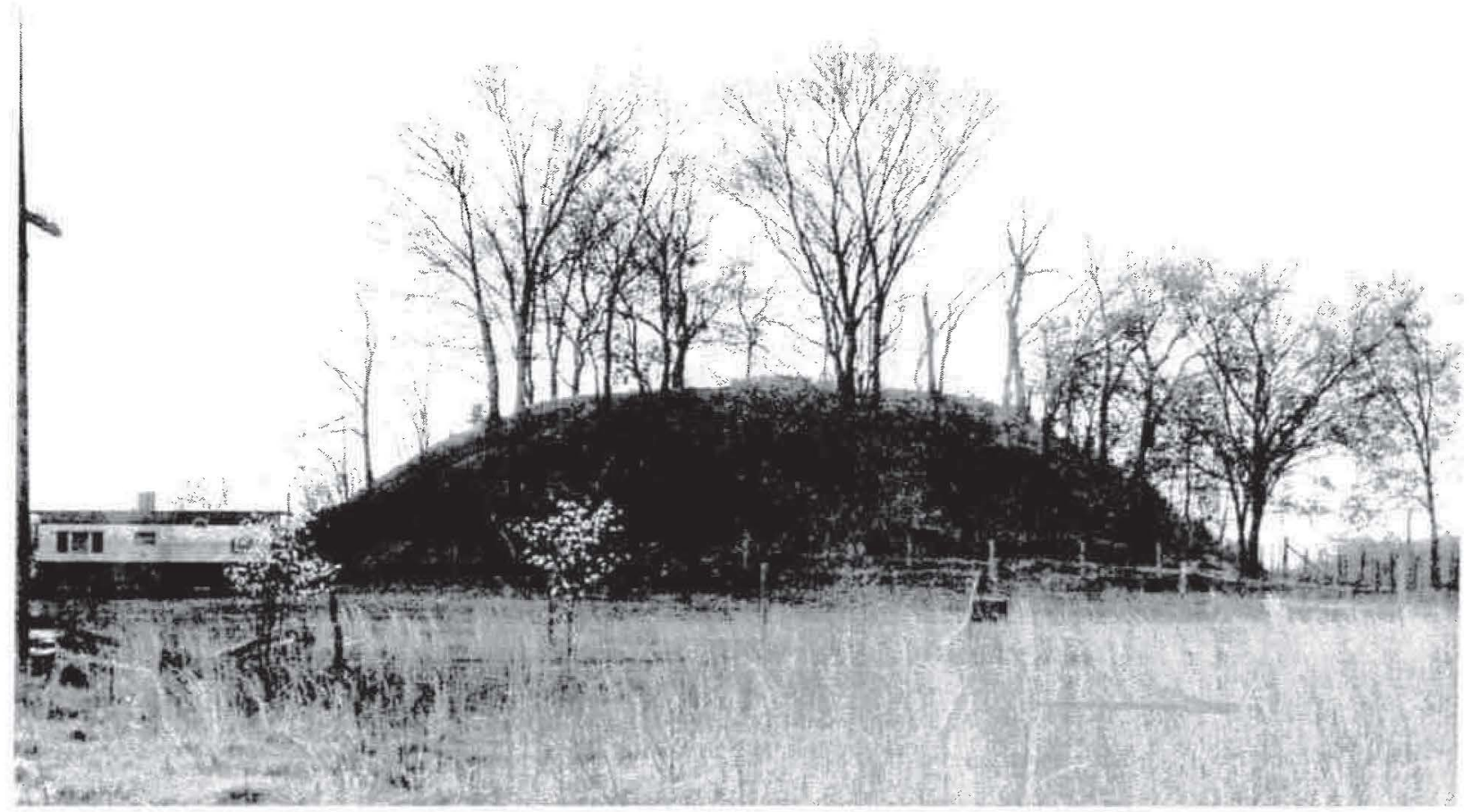

Figure 7. Clyde Dollar photograph of the mound, taken in 1958. Facing West. The eastern tunnel is open. Photo from University of Arkansas Museum. 


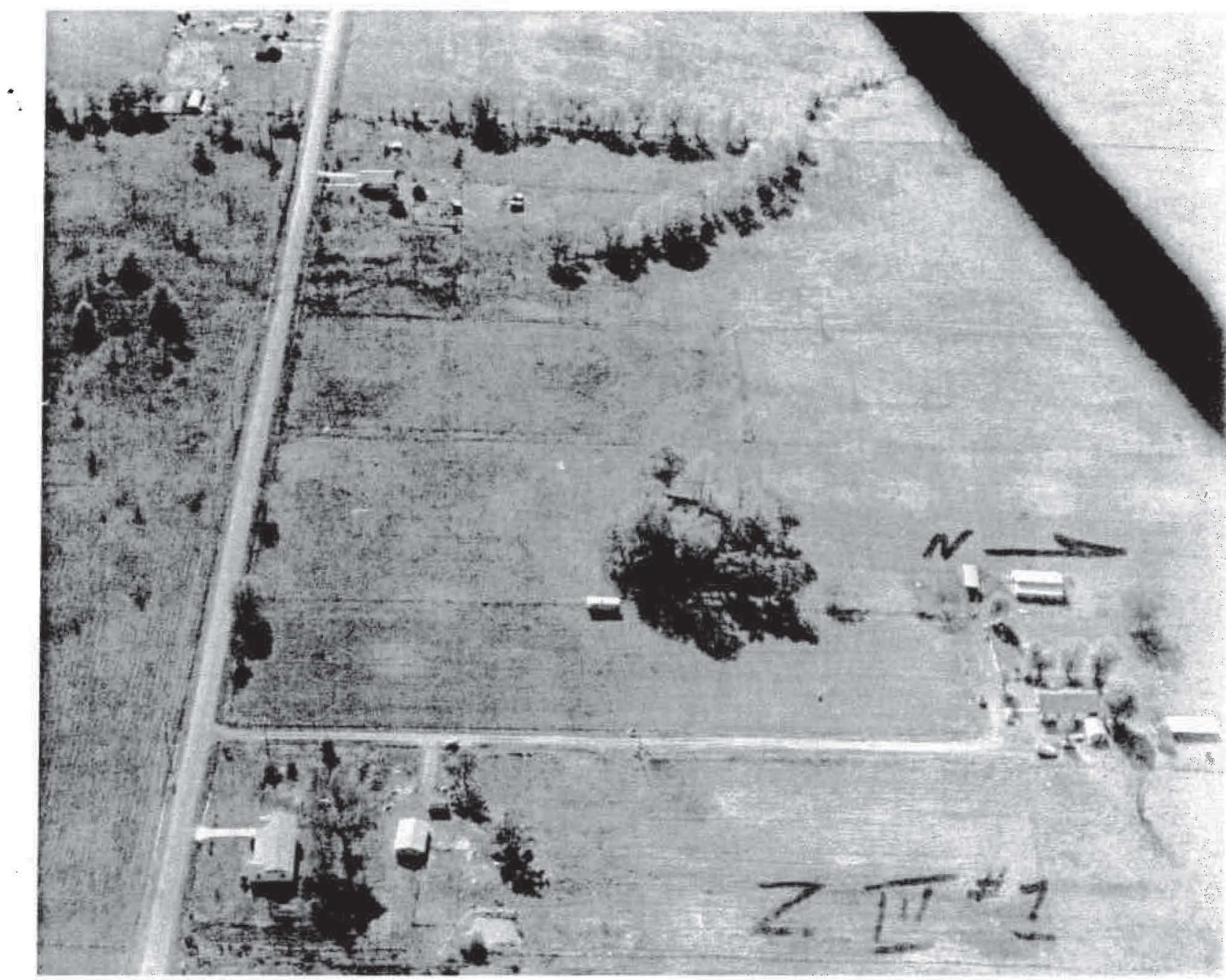

Figure 8. Clyde Dollar photograph of the mound, taken in 1958. North is to the right. The mound is in trees near the center of the photograph. The flat summit is visible as a cleared area. Photo from University of Arkansas Museum.

but it is unclear whether more had been cut away than in Dollar's slides. The AAS site revisit form from this trip reads:

Mound site once cut by large equipment does not appear to have been cut into for some time. No new holes on top of mound or erosion on sides. No gravestones could be located on either the mound top or at the base. A fresh backhoe trench along the access road some 100' off the mound did not have any artifacts present or evidence of prehistoric disturbance or occupation. (AAS Site files for 3SB3)

Neal Trubowitz and other AAS personnel visited the site in 1979 to check on the mound's condition. Trees and dense underbrush covered much of the mound at this time, and footpaths crossing the summit were eroding into it. The eastern tunnel, which had been exposed along the cut in the eastern edge, was sealed at this time. A local resident reported that he had been in the tunnel before it was sealed, and that it went about $6 \mathrm{~m}$ into the mound and opened up into a room large enough for a person to stand up in. This was likely the "potato cellar" mentioned in Dollar's (1958) report.

At this time the cut into the eastern face had been expanded, exposing a straight, vertical profile through much of the mound, extending from the ground surface to near the very top of the mound. Figures 10 and 11 show the cut as it appeared in 1979. Exactly when and why the entire eastern face was cut away is not recorded. 


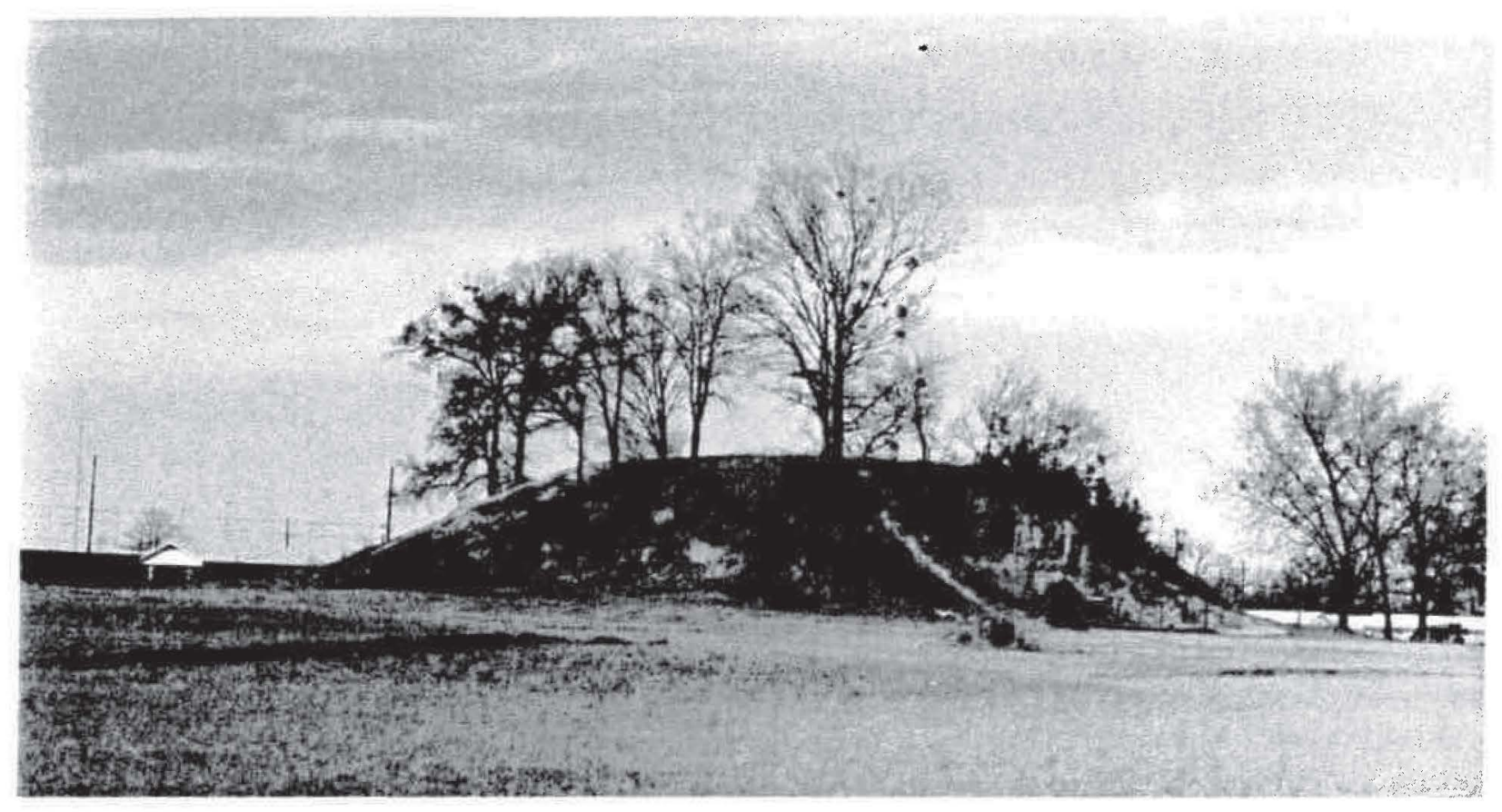

Figure 9. Clyde Dollar photograph of the mound, taken in the $1960 \mathrm{~s}$. Facing northwest. The eastern face of the mound had been partly removed in this photograph. The southern tunnel is backfilled in this photograph, but the slope of the mound above it is slumping. Photo courtesy of University of Arkansas Libraries, Clyde Dollar Manuscript collection, MC489, slide 25.

An access road for a trailer park passes just east of the mound, and the cut may have been made in order to make room for this road. The cut is still vertical and largely intact in the 1979 photographs, suggesting that it had not been exposed for a long time. The photographs from this visit are black and white only, and the profile cut is quite rough, so little stratigraphic detail is visible.

The eastern tunnel is covered by corrugated metal in the 1979 photographs, but the profile immediately around the tunnel opening shows a widened area where the tunnel emerges from the mound. Above this widened area, the profile is cut back further with clearly visible, apparently recent, shovel marks. The tunnel may have begun collapsing as the cut was made, creating a cavity as an artifact of the recent construction, or the cavity may represent the "potato cellar" at the end of the eastern tunnel shown on Newkumet's 1940 map and mentioned in later descriptions. The area above the cavity may have been cut away for safety, in order to keep it from collapsing into the cavity below.

No gravestones could be found during the 1979 visit, although Trubowitz reported (in an AAS site revisit form) that the dense undergrowth on the top of the mound could easily have obscured any gravestones present. The only material noted or collected at this time were some pieces of bone near the top of the mound (later identified as turtle, of recent origin), and a historic metal button or closure.

Jerry Hilliard visited the site again for the AAS in 1981 and noted severe erosion along the cut eastern face. A large pothole was visible at the top of the mound near the eastern edge, and two areas along the eastern profile had been recently scraped with a shovel. Foot trails and motorbike paths were continuing to entrench into the mound. No artifacts were found in these disturbances. Hilliard also examined areas of recent construction and grading a few hundred meters from the mound at this time, but found no features or artifacts. 


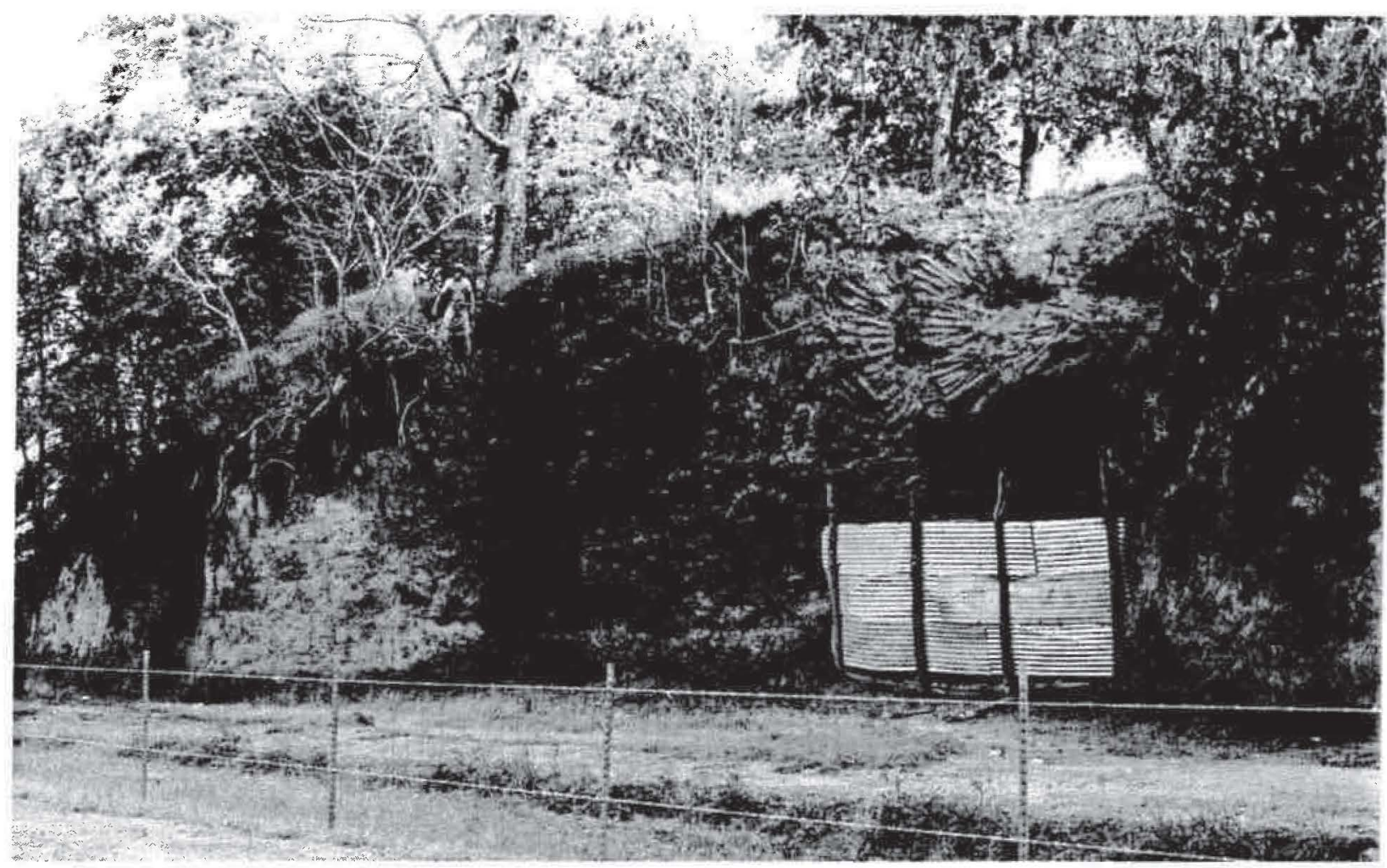

Figure 10. Photograph of the eastern cut into the mound, 1979. Facing west. Note the shovel marks above the area covered by corrugated metal. AAS negative \# 794342 .

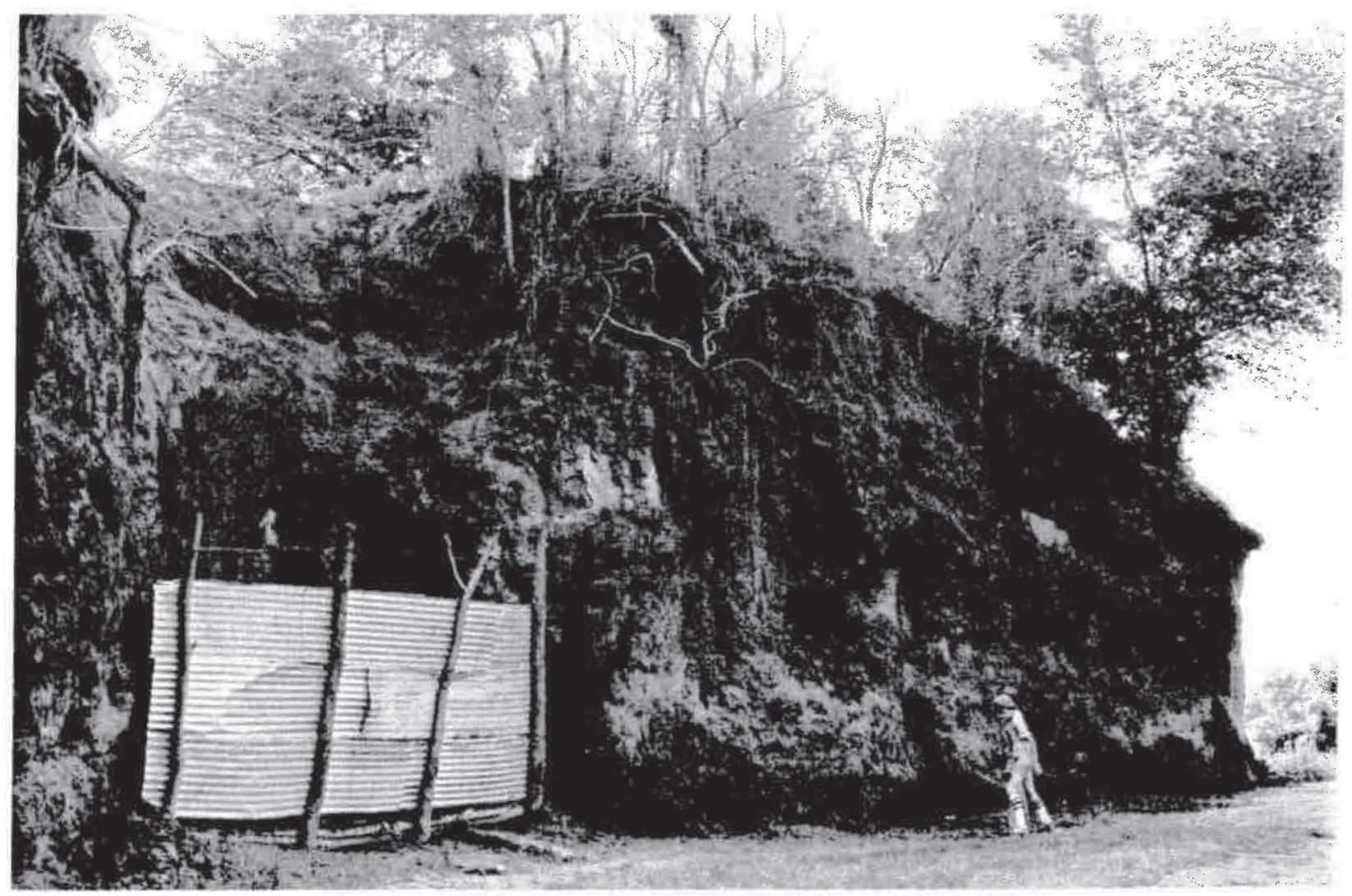

Figure 11. Photograph of the eastern cut into the mound, 1979. Facing west. AAS negative \# 794346. 
The eastern face continued to erode and the tunnel into the east face was re-exposed by 1991, when the site was visited by Arkansas Archeological Society member Mark Orsbun. Orsbun scraped a short section of the eastern profile clean, about $3 \mathrm{~m}$ above the surrounding ground level. This profile exposed several different colors of fill (yellow, red, and brown), and two lenses of charcoal. No samples were taken, and there are no photographs from this visit.

The eastern tunnel was plugged with rebar and concrete sometime during or after 1991, but was later reexposed by local children. In 1994 Jerry Hilliard and George Sabo of the AAS visited the site with City of Fort Smith workers, who were there to plug the opening again. At this time Hilliard reported that "basket loading" was visible in a profile near the tunnel, and " $1.7 \mathrm{~m}$ above ground surface at this point a probable mound stage division could be seen" (AAS site files for 3SB3).

The site was visited by myself several times from 2002-2004, and by myself and Jerry Hilliard, Michelle Berg Vogel, and Bob Dalton in 2004 in order to make a formal map documenting the remains of the mound. The condition of the mound continues to deteriorate: foot paths and sledding runs are entrenching more deeply into several sections, and the eastern face is still eroding back from the cut. Sediment washed from the exposed profile is accumulating at the base of the cut, and now forms a 4 to $5 \mathrm{~m}$ tall "ramp" up to the tunnel. The rebar and concrete plug over the tunnel have again been removed, and (as of late 2004) it is still open and occasionally visited by local children. A local resident reported that a tire had been set on fire in the tunnel several years ago, which the fire department was called to extinguish. There are several large depressions near the northeastern quarter of the summit, which may be pot holes or sunken graves. Aside from the cleared paths the mound is covered in dense underbrush and modern trash. The majority of the mound, however, appears to be intact.

\section{Size and Shape of the Mound}

Earlier reports estimated the mound to be as little as $43 \mathrm{~m}$ and as much as $64 \mathrm{~m}$ on a side, and from 7.5 to $12 \mathrm{~m}$ tall (Table 1). These estimates do not appear to be based on formal data from mapping instruments, and it is unclear whether the authors used tape measures, pacing methods, or dead reckoning to come up with the numbers. It is therefore not surprising that such variation exists. A topographic map of the mound made with a total station in 2004 (Figure 12) shows the current configuration of the mound. The mound is currently about $9 \mathrm{~m}$ above the surrounding ground level. A broad alluvial apron of sediment surrounds the mound, extending 10-30 m out from what was likely the base of the mound when it was constructed. The upper portion of the eastern face of the mound is cut and exposes a nearly vertical profile, while the lower half of the eastern face is covered by material eroded from above.

The mound is about $50 \mathrm{~m}$ north to south, although judging where the original mound edges were located is difficult given the current vegetation and the erosion the mound has experienced. East to west the mound is about $40 \mathrm{~m}$ wide. Photographs from 1979 (see Figures 10 and 11) show the entire eastern face of the mound cut back to vertical, but the southeastern portion was not cut back as far. The projection off of the southeast comer is still expressed in the mound topography. The flattish summit portion of the mound is about $20 \mathrm{~m}$ side to side. There is a small, low mound off of the northeast corner of the main mound, which may be intact mound sediment, or may be spoil from the cut into the eastern side. Extrapolating from the preserved portions of the mound, its size falls well within the range given by the four early descriptions (see Table 1). Except for the cut in to the eastern side, in fact, it appears to be remarkably intact. 
Table 1. Early descriptions of Cavanaugh.

\begin{tabular}{|c|c|c|c|c|}
\hline & $\begin{array}{l}\text { Newkumet } \\
(1940)\end{array}$ & Shaeffer (1956) & $\begin{array}{l}\text { Rogers (1958) } \\
\text { and Bell (1980) }\end{array}$ & Dollar (1958) \\
\hline Dimensions & $\begin{array}{l}61 \mathrm{~m} \mathrm{~N} / \mathrm{S} \\
61 \mathrm{~m} \mathrm{E} / \mathrm{W}\end{array}$ & $\begin{array}{l}30.5 \mathrm{~m} \text { in } \\
\text { diameter }\end{array}$ & $\begin{array}{l}49 \mathrm{~m} \mathrm{~N} / \mathrm{S} \\
64 \mathrm{~m} \mathrm{E} / \mathrm{W}\end{array}$ & $\begin{array}{l}43 \mathrm{~m} \mathrm{~N} / \mathrm{S} \\
46 \mathrm{~m} \mathrm{E} / \mathrm{W}\end{array}$ \\
\hline Height & $12 \mathrm{~m}$ & $9.1 \mathrm{~m}$ & $7.5 \mathrm{~m}$ & (none given) \\
\hline $\begin{array}{l}\text { Dimensions } \\
\text { of flat top }\end{array}$ & 26.1 by $26.1 \mathrm{~m}$ & (not given) & 21.3 by $21.3 \mathrm{~m}$ & 18.3 by $18.3 \mathrm{~m}$ \\
\hline Cemetery & $\begin{array}{l}\text { Sketched on } \\
\text { NE quad of } \\
\text { summit; at } \\
\text { least six graves } \\
\text { shown }\end{array}$ & $\begin{array}{l}\text { Several from } \\
\text { "middle } 1800 \mathrm{~s} "\end{array}$ & $\begin{array}{l}\text { About } 16 \text { burials, } \\
12 \text { marked } \\
1881 \text { to } 1895\end{array}$ & $\begin{array}{l}\text { At least } 12 \\
\text { marked } \\
1833 \text { to } \\
\text { "beginning of } \\
20 \text { th century" }\end{array}$ \\
\hline East Tunnel & $\begin{array}{l}\text { Shown on } \\
\text { sketch }\end{array}$ & \multirow[t]{2}{*}{$\begin{array}{l}\text { One tunnel } \\
\text { mentioned, no } \\
\text { location noted. }\end{array}$} & $\begin{array}{l}\text { Dug } 1908 \\
6 \mathrm{~m} \text { long }\end{array}$ & $\begin{array}{l}\text { Dug } 1898 \\
18 \mathrm{~m} \text { long - } \\
\text { became potato } \\
\text { cellar }\end{array}$ \\
\hline $\begin{array}{l}\text { South } \\
\text { Tunnel }\end{array}$ & $\begin{array}{l}\text { Not shown on } \\
\text { sketch }\end{array}$ & & $\begin{array}{l}\text { Dug } 1898-1908 \\
7.5 \mathrm{~m} \text { long } \\
1.8 \mathrm{~m} \text { square room } \\
\text { at end. Etters } \\
\text { unplugged tunnel } \\
\text { and excavated } \\
\text { further into it. }\end{array}$ & $\begin{array}{l}\text { Etter dug } 6 \mathrm{~m} \\
\text { long tunnel in } \\
1957 \text {, } \\
\text { encountered } \\
\text { earlier tunnel }\end{array}$ \\
\hline $\begin{array}{l}\text { Other } \\
\text { Observations }\end{array}$ & $\begin{array}{l}1.8 \mathrm{~m} \text { high } \\
\text { "bench" } \\
\text { encircling base } \\
\text { of mound. }\end{array}$ & $\begin{array}{l}\text { Banding of light } \\
\text { and dark } \\
\text { colored fill; } \\
\text { burned clay }\end{array}$ & $\begin{array}{l}\text { Visited mound in } \\
1953 \text { and 1958; } \\
\text { "stratification" in } \\
\text { 6-inch layers }\end{array}$ & \\
\hline
\end{tabular}

Newkumet's 1940 sketch shows a bench around the base of the mound that is not mentioned in any later descriptions, and it is not expressed today in the topography of the mound. It is possible that Newkumet's "bench" was actually an accumulation of eroded material, forming an alluvial apron around its base. Loose material eroded from the top and sides (and possibly backfill from the historic internments on top?) could easily account for this. Newkumet's sketch shows a very sharply defined bench, though, and it is possible that this actually existed as it was drawn in 1940 and was only obscured by erosion after then. If this is the case, Cavanaugh would be the only mound in this region for which such a feature was recorded.

\section{Stratigraphy}

Earlier reports noted several different types of mound fill, sometimes in alternating bands or discernible basket loads. These were mostly observed in the walls of the tunnels. Much of the upper half of the eastern 


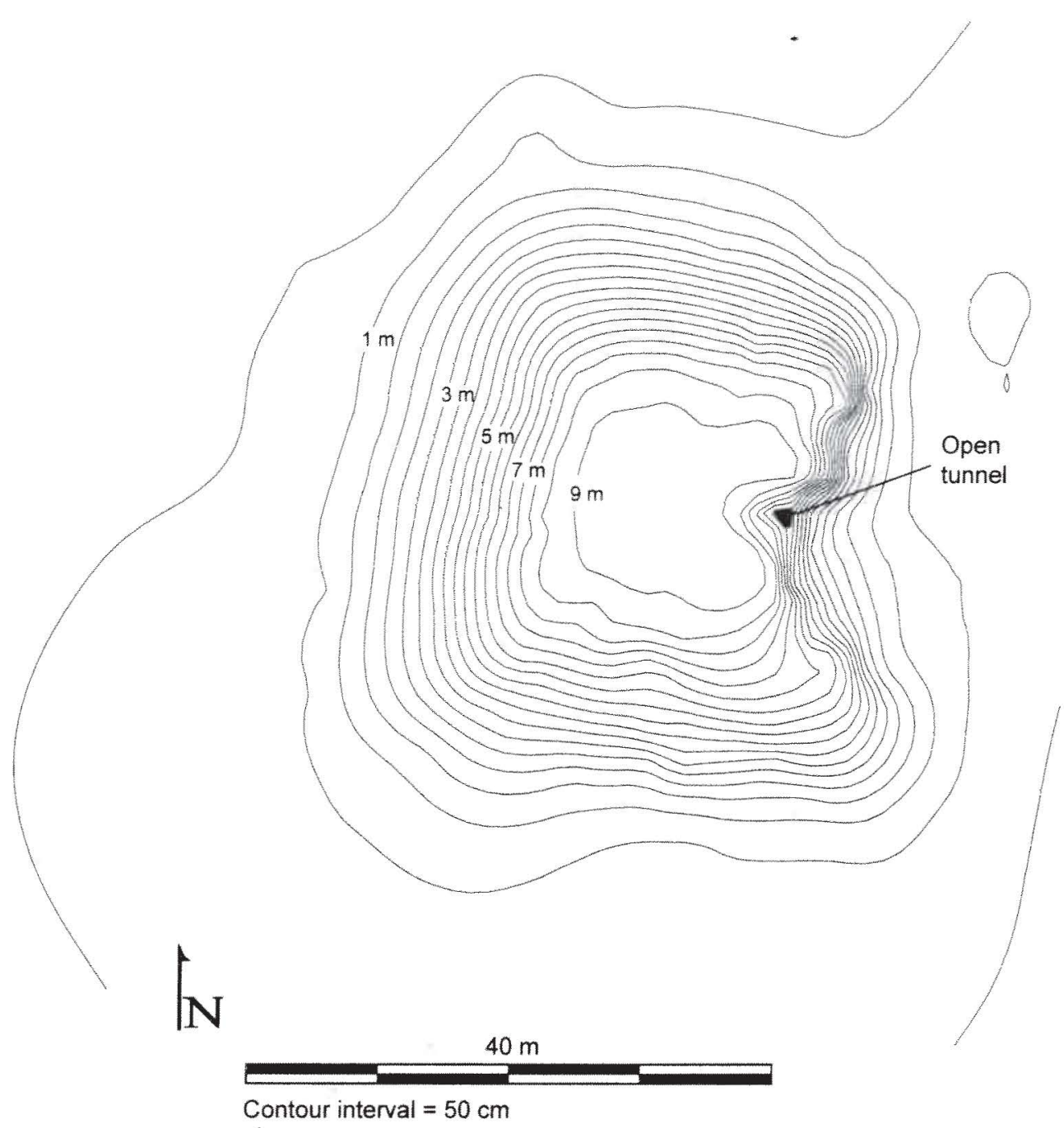

Figure 12. Contour map of Cavanaugh Mound, made with a total station in 2004. Several trails are entrenched into the mound $50 \mathrm{~cm}$ or more, but because of vegetation and time these were not mapped in detail and are not expressed in these contours.

profile is currently exposed, but is open to the elements and little of stratigraphic interest is currently visible without scraping back the outer layer. Investigations of the mound in 2004 included scraping clean several small areas of the exposed profile. In order to minimize damage to the mound and reduce the risk of further erosion, the cleaned areas were relatively small and separated from one another. No overall view of mound stratigraphy was therefore obtained, but several suggestive features were exposed.

Figure 13 shows a cleaned portion of the profile about $10 \mathrm{~m}$ south of the open tunnel. Individual loads of darker sediment are clearly visible in this area. The dark loading features are very dark gray (10YR3/1) silt loam, and the surrounding matrix is composed of brown (10YR4/3) and yellowish-brown (10YR5/4) silt loam. The sediment expressed a weak blocky structure, but this is likely due to weathering from the recently exposed profile. Within the matrix around the dark loading features were also a few small $(2-4 \mathrm{~cm}$ diameter) distinct clods of pale yellow (2.5Y7/4) sediment. Exposed in this small window alone, then, are at least three different types of fill. Earlier reports also noted several different types of fill, including sediment with and without pebbles. It seems unlikely that all the different fills originated in the area immediately surrounding the mound. 
Where the different sediments came from and how far they were transported remains an open question, as it does at many area platform mounds.

Extending from the open tunnel to about $10 \mathrm{~m}$ south is a clear horizontal unconformity in the fill (Figure 14). Through the windows of small scraped areas on the profile, this line appears to run the entire length of the mound. Redox concentrations (iron staining) and ferromanganese concretions are concentrated along this unconformity, indicating differential water flow above and below the line. A horizon about $10 \mathrm{~cm}$ thick below the line appears to be compacted, and composed of slightly different fill than the sediment below it. This horizon is reminiscent of mound stage divisions noted in other area platform mounds, such as the Huntsville site (Sabo 1986), GoforthSaindon (Kay et al. 1989), Harlan (Bell 1972) and Norman (Finkelstein 1940; Vogel et al. 2004).

\section{Artifacts}

No artifacts have been reliably reported as coming from the mound, or even from the general area around the mound. The surrounding field is in cultivation in several of the early photographs, so surface visibility has been good throughout much of the time the mound has been under investigation (Figure 15 and 16). Newkumet's 1940 notes make no mention of artifacts, and Shaeffer (1956:4) explicitly states the lack of artifacts found on or around the mound. The current land owner, Frank Etter, recalls recovering no artifacts even after continuing excavations into both the east and south tunnels (personal communication 2004). More recent investigators have failed to find artifacts as well. At least 10 archeologists from the AAS and other institutions have visited the site since 1972, and found no prehistoric artifacts. Much of the mound's internal structure has been exposed during this time. Numerous AAS archeologists have also examined ground cleared for construction, foundation trenches, and other disturbances in the area immediately surrounding the mound, again without finding a single artifact or feature.

Aside from the mound itself, no prehistoric sites have been reported within a radius of about $5 \mathrm{~km}$. At least three cultural resource management surveys have been conducted within a few $\mathrm{km}$ of the site (Heartfield, Price and Greene, Inc. 1984; Hilliard 1981; McAlexander 1994). Although these surveys were all fairly limited in scope, all included surface and subsurface investigations, but failed to recover any prehistoric artifacts.

There are three references to artifacts from the site descriptions above. AAS personnel found turtle shell of recent origin and a historic button or closure on the mound in 1979; neither relate to the prehistoric construction or use of the mound. Dollar (1958:2) notes that while he had found no artifacts personally, "other individuals have made small finds, some dubious as to relationship to the mound, and all somewhat inconclusive. Among these finds was one small potsherd, found in the southwestern quarter of the field immediately around the mound, [and] the stone end of a war club, broken and of poor quality." In his letters to both McGimsey and Bell, Rogers (1958:3) reports being told that "a number of fine artifacts had been recovered" from the southern tunnel.

Dollar's reported artifacts, as he states, are of "dubious relationship" to the mound, and Rogers' reports are rumors of artifacts found 50 to 60 years earlier. It is impossible to dismiss Rogers' report entirely, but it seems likely that if "a number of fine artifacts" had been found there would be more of record of the find than one vague rumor.

\section{The Tunnels}

Tunnels were excavated into the east and south sides of the mound, and both of them may date to the $1890 \mathrm{~s}$ or earlier (see Table I for a summary of descriptions). The purpose for these early tunnels is unclear. They both 


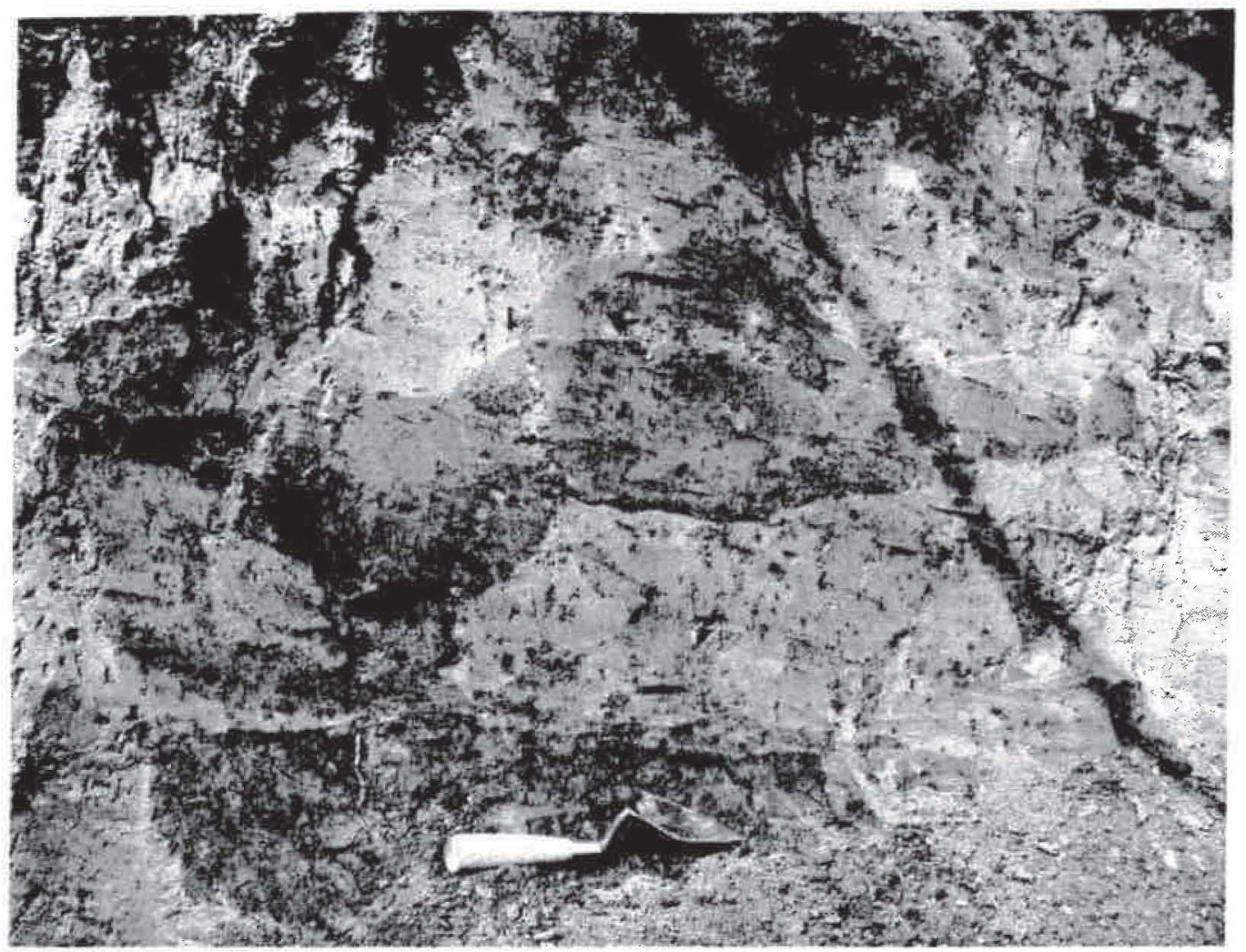

Figure 13. Loading features visible in the mound profile, about $10 \mathrm{~m}$ south of the open tunnel.

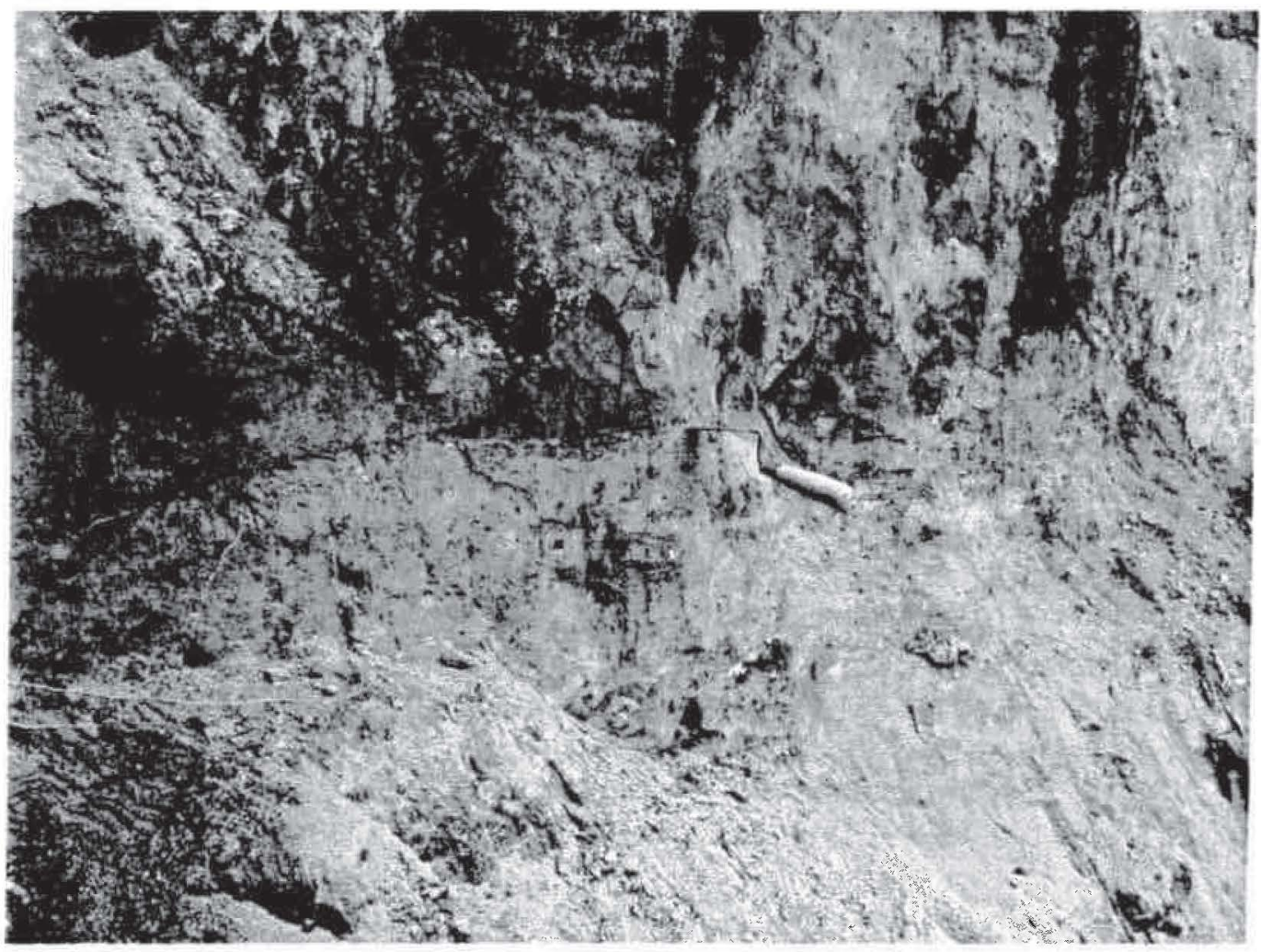

Figure 14. Possible mound stage division visible in profile, about $5 \mathrm{~m}$ south of the open tunnel. 


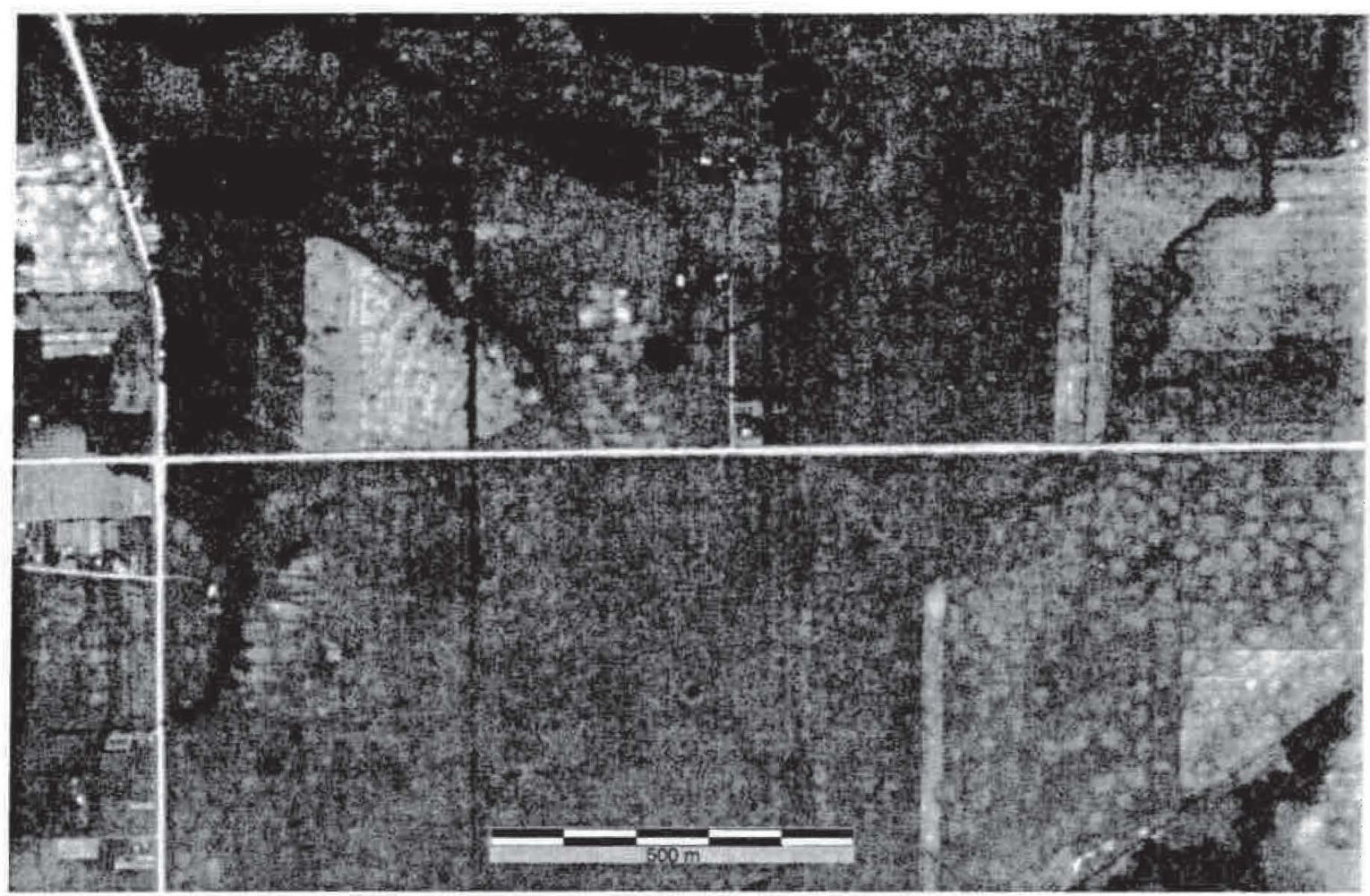

Figure 15. Aerial photograph taken in July of 1938. North is to the top. Arrow points to the mound. The summit is visible as a cleared patch surrounded by trees. Prairie mounds cover virtually all the exposed ground. Note the prairie mounds expressed as lighter colored patches just west of the mound. USDA aerial photo AWA-6-32.

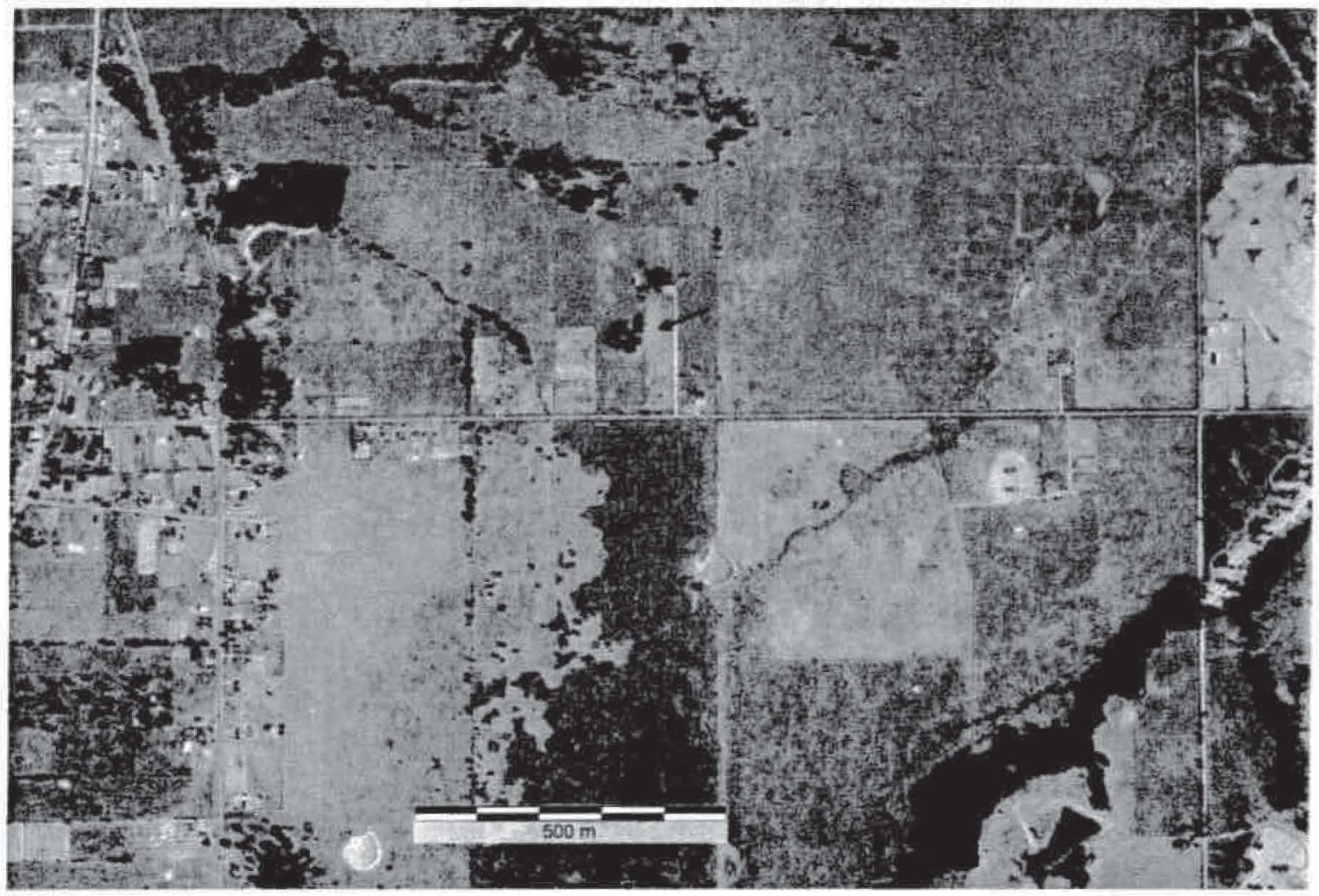

Figure 16. Aerial photograph taken in August of 1954. North is to the top. Arrow points to the mound. USDA aerial photo AWA- $1 \mathrm{~N}-12$. 
apparently originated well before the 1930 s, when the discovery of spectacular artifacts at the nearby Spiro site led to tunneling and large-scale excavations of many of the mounds there. Whether the tunnels were originally excavated for storage spaces or as amateur explorations into the mound, they ended up being used for both. The south tunnel appears to have been backfilled, or at least the opening of it was plugged, by 1940 when Newkumet made his sketch of the mound (see Figure 2).

The east tunnel was open and at least occasionally used for storage until the $1970 \mathrm{~s}$, when it was plugged for safety concerns. The tunnel has been opened and re-plugged several times since then. Beginning around 1957 Frank Etter continued excavation into the east tunnel, and re-opened the south tunnel for excavation. Etter reportedly found an open room at the end of the south tunnel, although Dollar (1958) states that he found no evidence of this. A substantial room existed at one time connected to the eastern tunnel (the "potato cellar"), and may still exist. Note that there are no claims that these rooms were part of the original mound and were "discovered" by the historic tunneling efforts - every indication is that they were created in historic times as part of the tunneling efforts.

The eastern tunnel is currently open (as of late 2004). The tunnel is about $1 \mathrm{~m}$ wide and just over $1 \mathrm{~m}$ high, extending into the mound for at least $15 \mathrm{~m}$. At least one side-tunnel branches off to the north. Trash litters the tunnel throughout. Safety considerations precluded a thorough examination of the tunnel deep into the mound during the 2004 visit.

\section{The Historic Cemetery}

All that remains of the historic cemetery at the summit of the mound are a few depressions that may mark the locations of individual graves. Descriptions from observers who actually saw the cemetery intact vary slightly in the number and dating of the graves (see Table 1), but it is clear that the cemetery contains a dozen or more burials from the $1800 \mathrm{~s}$. None of these reports contain information about the gravestones except for bracketing dates. The last mention of intact gravestones at the cemetery are from Dollar (1958), who also reports observing "what was reputed to be a human skull, in badly mutilated condition, taken from a three foot grave at the top of the mound" (Dollar 1958:2). It is therefore possible that one or more of the graves was looted prior to 1958.

An 1887 land plat of Sebastian County (Hayes 1887) shows the land under the ownership of Henry Stappleman ("Stappleman" is either a misspelling or an earlier variant of "Stoppleman"). A plat book from 1903 shows that the land was divided and the mound was owned by Mrs. B. Stoppleman (Foote 1903). In a short article on Cavanaugh Mound in the Journal of the Fort Smith Historical Society, Minor (1995:16-17) reports that the gravestones were removed before 1968, but that broken pieces had been found sometime after then. The only piece with writing contained the epitaph "Truth was her motto and God her trust" (Minor 1995:17). Minor also reports that Fort Smith Putman Funeral Home records show that 12 members of the Stoppleman family were buried on the mound between 1890 and 1900. A few local informants remembered seeing the Stoppleman name on the gravestones, but could recall no other details.

Minor (1995:17) relates a story of one of the Stoppleman descendents visiting the cemetery:

During the last decade an elderly visitor to the graveyard on the mound, paying respect to a relative, believed himself to be one of the two remaining survivors of that family. Within his memory he recalled his kin owning the farm at the turn of the century. He remembered the tunnels in the mound were used for storing hay and grain. 
All accounts agree that the cemetery is located on the summit of the mound, and Newkumet's sketch shows the cemetery in the northeast quarter of the summit. It is unclear whether this sketch reflects the full extent of the cemetery. The depressions currently visible on the summit (which may mark the location of sunken graves) are within the northeast quarter. There are no clear photographs of the grave plots or marker stones, but one of Dollar's photographs (from 1958) shows features that appear to be displaced grave stones, near the bottom of the western slope of the mound (Figure 17). This photo also shows horses grazing on and around the mound, which may well account for the overturned and displaced stones.

The cut into the eastern portion of the mound reaches from the ground surface up to the top of the mound, and may extend past the eastern edge of the summit itself now. Particularly if the cemetery were located on the eastern portion of the summit (as depicted in Newkumet's 1940 sketch), it is in danger of being disturbed as the eastern cut continues to erode westward into the mound.

\section{The Gift Shop}

Sometime during the late 1950s or early 1960s landowner Frank Etter set up a large, wooden teepee-shaped gift shop and attempted to turn the mound into a tourist attraction. The teepee can be seen in a postcard of the site from its tourist-attraction days (Figure 18). The gift shop sold souvenirs and trinkets, but no prehistoric artifacts. Arkansas Archeological Society member Bob Dalton (personal communication 2004) recalls visiting

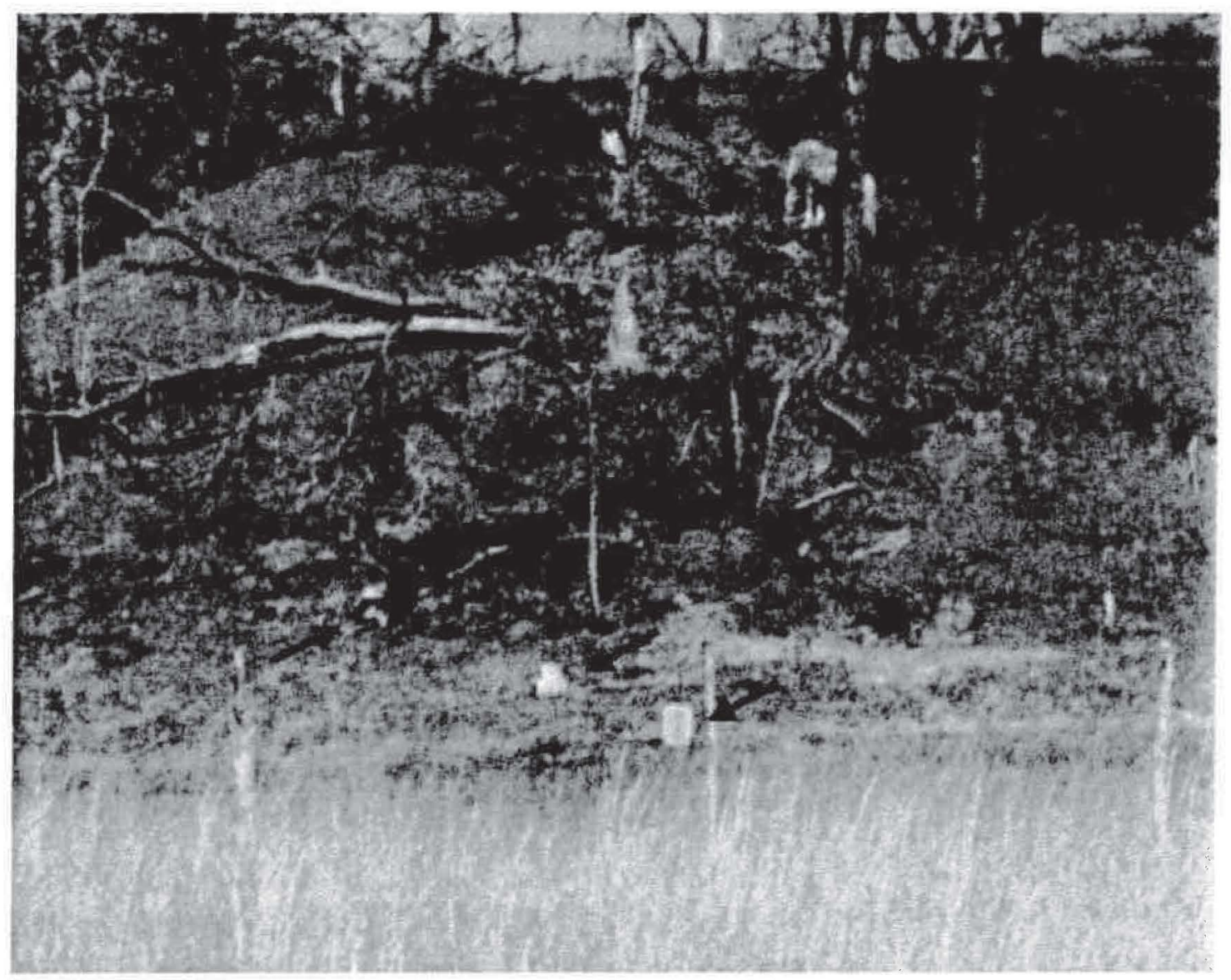

Figure 17. Close-up view of Figure 5. Arrows point to features that appear to be displaced gravestones. 
the site as a child sometime around 1960. At the time, the mound was being advertised as a tourist attraction on a local country music radio station, which touted not only the mound and teepee gift shop, but rides for children in a stagecoach drawn by four Shetland ponies.

The tourist attraction was a short-lived venture, only lasting a few seasons. The teepee gift shop was taken down sometime in the 1980s. The land on which the teepee stood is now owned by a church adjacent to the mound, and only the circular, concrete slab foundation remains.

\section{Aerial Photographs}

Two early aerial photographs, one from 1938 (see Figure 15), and one from 1954 (see Figure 16), show Cavanaugh Mound and the surrounding terrain before much of it was covered by urban development. The 1938 photograph may be the earliest image of Cavanaugh ever taken. The mound's location is clearly visible in both images as a patch of trees surrounded by cultivated fields. The cleared summit of the mound is also visible in the 1938 image, but the resolution of the photographs is too low for finer details to be expressed.

Naturally occurring prairie mounds are visible in both photographs, covering the entire landscape for several hundred $\mathrm{m}$ around the mound. Prairie mounds occur throughout much of the western United States, generally occurring in large fields within river floodplains or terraces. In areas where they are not plowed, eroded, or otherwise disturbed by modern land use practices, they are generally one to two meters tall. The prairie mounds surrounding Cavanaugh are about $20 \mathrm{~m}$ in diameter and closely spaced, creating a regular pattern across much of the landscape. The soil stratigraphy of prairie mounds is ideally suited to studies of prehistoric landscape modification.

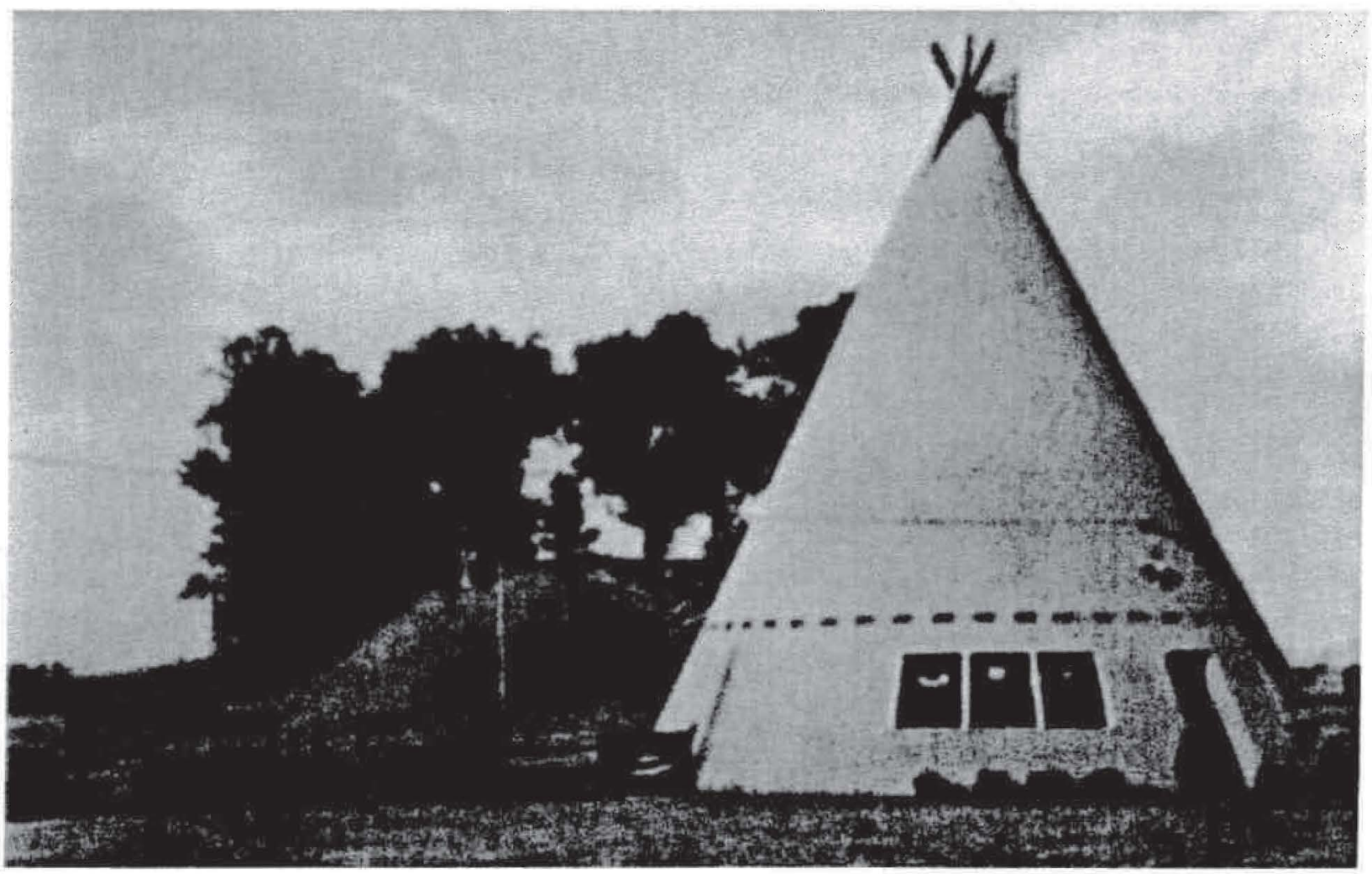

Figure 18. Undated postcard of Cavanaugh Mound with a tourist-shop teepee in front. 
Because the upper, organic-rich A horizon contours the surface of the mounds and is darker than the underlying soil, the truncation or leveling of a mound leaves behind a lighter-colored patch where the mound used to be. Such patches are easily identified in aerial photographs as distinct from un-truncated prairie mounds, indicating a landscape modification at least more recent than the time it takes for a well-developed A-horizon to form.

Immediately west of the mound (see Figure 15) is an irregularly-shaped area of apparently truncated prairie mounds, not corresponding to any field edge or other historic land use pattern. These are not as well expressed in the 1954 aerial photograph (see Figure 16), possibly due to moisture conditions or ground cover. These mounds may have been leveled long before the fields were plowed in historic times, possibly contemporaneous with the mound construction or use. The prairie mounds may have been used for mound fill, or the area may have been leveled flat for use as a plaza within an area of otherwise undulating topography.

The majority of the land in both photographs is in open field. Within $1 \mathrm{~km}$ of the mound, only about $13 \%$ ( 42 out of 314 hectares) is covered by trees or buildings that obscure the prairie mound pattern (determined through a simple GIS model derived from the aerial photographs). Besides the patch just west of Cavanaugh, there are no disruptions in the regular patterns made by prairie mounds that are not accounted for by modern land-use practices. Cavanaugh Mound therefore appears to be alone on the landscape, and not part of a group of mounds in close association.

\section{Viewsheds}

Although quite speculative at this point, there are some suggestive relationships among the viewsheds of Cavanaugh Mound and mounds at the Spiro and Skidgel sites. I offer this analysis as one way to view the possible relationships of the mounds on the landscape and in relation to one another. GIS viewshed analysis is necessary for testing the potential inter-visibility of the sites because of historic changes to the landscape. Dense vegetation on the mounds, houses and other buildings, and high road embankments now block much of the view, making it impossible to determine what would have been visible in prehistoric times simply by going to the mounds and looking.

A "viewshed" is the sum of what can be seen from any particular point on the landscape. From a digital elevation model (DEM) in GIS we can specify a location, the height of the viewer, a maximum potential distance to which a person can see, and derive an output showing us which portions of the landscape would be in view. The viewsheds in this analysis are based on U.S. Geological Survey DEMs with $30 \mathrm{~m}$ resolution. There are several considerations which much be kept in mind when employing such viewshed studies, however. Atmospheric haze can often limit the maximum distance from which features can be seen, for example (termed distance decay), and modern landscape changes expressed in DEMs can significantly alter viewsheds from what they would have been in prehistoric times.

Modern landscape changes in the Cavanaugh area that have the potential to alter the viewshed include tall road embankments and changes in the course of the Arkansas and Poteau rivers due to natural meandering and intentional modification. The road embankments are easily "erased" from the DEM and leveled to the elevation of the surrounding ground. The river channels may be similarly altered in the DEM to reflect previous positions, but I do not consider this necessary for the current study. The exact course of the rivers will affect the viewsheds within the bottomlands in possibly significant ways, but because the mounds are above the floodplain itself, the exact river location will not alter the potential inter-visibility of the sites, or the overall shape and size of the viewsheds in general. 
I also do not consider distance decay to be a significant factor for this study. The sites in question are relatively close to one another (Cavanaugh and Skidgel are only about $16 \mathrm{~km}$ apart), and historic precedence shows us that atmospheric conditions in the region were often clear enough to allow for far greater lines of site. Thomas Nuttall's journal of his travels through the area in 1819, for example, includes the following passage for April 24:

This morning we passed the hills of Lee's Creek, which, for a short distance, borders the Arkansas, and about noon arrived at the garrison, which comes into view at the distance of about four miles, agreeably terminating a stretch of the river. Rising, as it were, out of the alluvial forest, is seen from hence at a distance of 35 miles, a conic mountain nearly as blue as the sky, and known by the French hunters under the name of Point de Sucre, or Sugar Loaf. (Nuttall 1821:197).

Tall vegetation can also obstruct views, but is not accounted for in the topography of DEMs. For the bottomlands I do not consider this to be a hindrance in determining the overall viewsheds or inter-visibility of the sites. Cavanaugh, Brown, and Skidgel mounds are all located on terraces above the bottomlands and several meters tall. Even relatively high vegetation in the bottoms would not obstruct the views from one site to another. Trees or other vegetation on the terraces near the mounds could easily block the views, however, and there is no way of reconstructing exactly what vegetation was present at specific times in the occupation of the sites. I therefore consider the following examples to be the maximum potential viewshed for each specific location, and not necessarily the exact viewsheds actually existing prehistorically. From what we know of the nature of the mounds, however, particularly the public nature of their construction and the use of colorful and contrasting colors for fill, it seems unlikely that they would have been intentionally screened from view. Possibly the ability to see the mounds from a great distance was even a consideration in deciding where to locate them.

For this analysis I used a somewhat conservative viewing height of $150 \mathrm{~cm}$ as the approximate eye-level for a prehistoric person of average height. The maximum viewing distance was set at $25 \mathrm{~km}$. This is large enough to encompass all three sites, but small enough that edge effects from the curvature of the earth are negligible.

Figure 19 shows the viewshed from the ground level at the location of Cavanaugh Mound. Cavanaugh Mound is substantial enough on the landscape that it is expressed as a topographic high even on the U.S. Geological Survey $30 \mathrm{~m}$ DEM. For this analysis, the DEM was altered to produce a level surface in the location of Cavanaugh Mound, effectively "erasing" it from the landscape. The light areas in this figure thus represent what a person would be able to see, if no tall vegetation were present, standing at the location of Cavanaugh, before the mound was constructed. The light areas also represent portions of the landscape from which that person would be visible. The viewshed is primarily directed to the west and northwest, overlooking the Poteau/Arkansas River bottoms. The Arkansas River off to the east is out of sight. A low rise in the landscape about $150 \mathrm{~m}$ west of Cavanaugh blocks the view down into the southern part of the bottoms. A few of the hills above the bluff line to the north of the Arkansas River are visible as well. The viewshed from this analysis covers about half of the Spiro site, and comes within about $90 \mathrm{~m}$ of Brown Mound. $90 \mathrm{~m}$ in a DEM with $30 \mathrm{~m}$ resolution is of course only equal to 3 raster cells, and it would be unwarranted to assume accuracy of the model at this level of detail. What we can say is that from the ground surface, the Cavanaugh and Spiro areas may have been just barely visible to one another. If there were even low vegetation on the ground, however, the view would have been totally obscured. Skidgel Mound, even though it sits on a local topographic prominence, is obscured by the landscape alone in this analysis, even without the added obstruction of vegetation.

Adding $9 \mathrm{~m}$ of height to the viewer's elevation and repeating the analysis results in the viewshed shown in Figure 20. This represents the landscape viewable from the top of Cavanaugh Mound, and, possibly more importantly, the areas on the landscape from which Cavanaugh Mound itself would be visible. The viewshed off to the west overlooking the Poteau/Arkansas River bottoms is now much wider, and the Spiro and Skidgel 


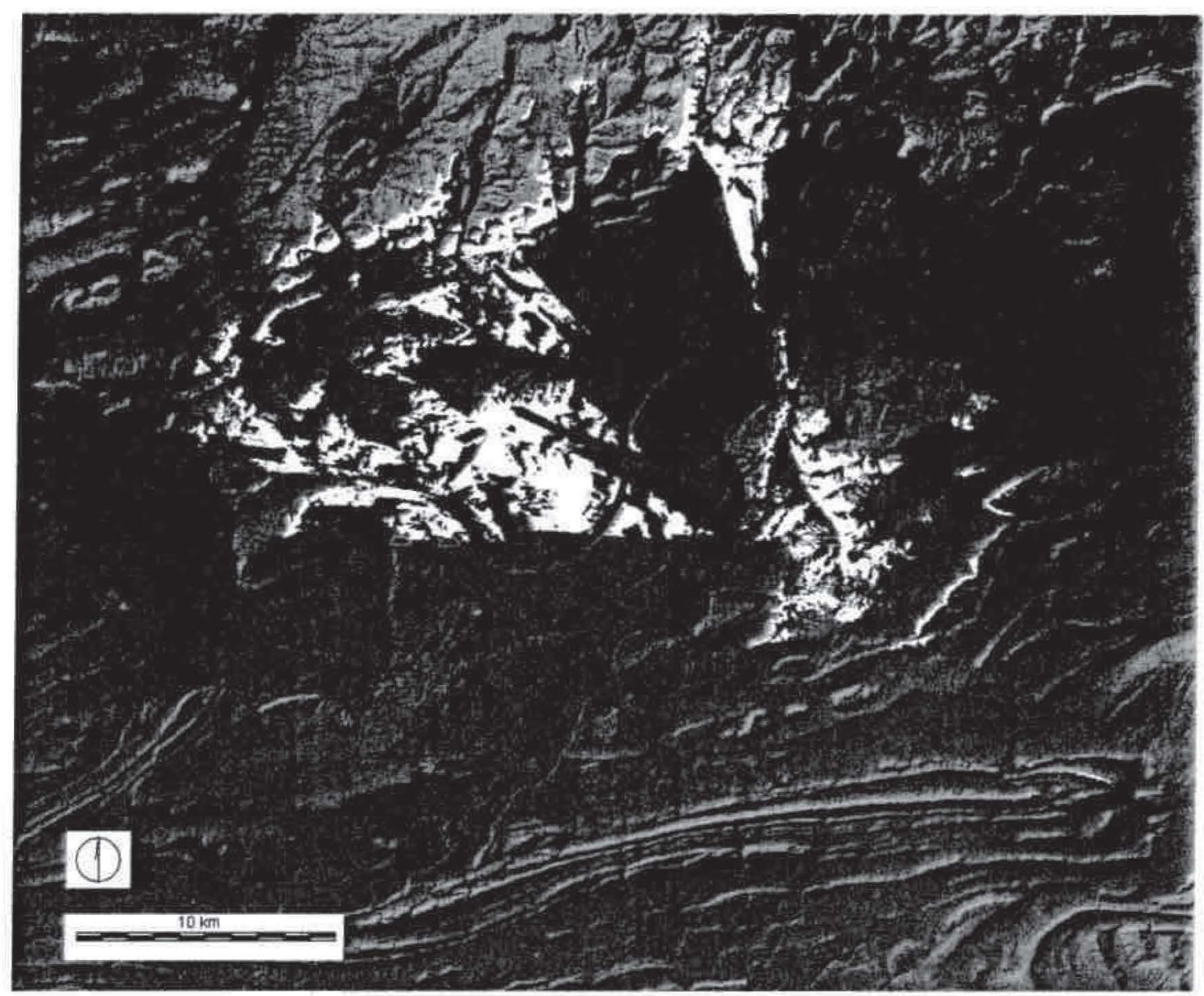

Figure 19. Viewshed from ground level at the location of Cavanaugh Mound. The Spiro and Skidgel sites are possibly within view, but would have easily been obscured by vegetation.

sites are clearly within view. Even relatively tall vegetation in the bottoms would not obstruct this inter-visibility. The narrow views off to the east and north in this viewshed are somewhat suspect. The ground along these paths is not much lower than the mound itself, and any vegetation of even moderate height would completely obstruct these lines of sight. Unless these corridors were completely cleared of trees and tall bushes (for about $10 \mathrm{~km}$ to the east and about $6 \mathrm{~km}$ to the north), these views would not have been possible. The view off to the west may be more realistic. Cavanaugh Mound is just over $200 \mathrm{~m}$ from the sharp drop of the bluff line, and only tall vegetation within this area would block the view into the bottoms.

Figure 21 shows the viewshed from the top of Brown Mound, the largest platform mound at the Spiro site. The viewshed from Copple Mound, the other platform mound at the site, is substantially similar. This viewshed is primarily directed to the east, overlooking the Poteau/Arkansas River bottoms. Nearly all of the bottomland area between Cavanaugh and Spiro, in fact, is within this viewshed. Some of the hills behind the Arkansas River bluff line both to the north and to the south are within this viewshed. Although there is some lower-lying land between Spiro and Skidgel, the prominence on which the Skidgel Mound is located is well within view. As with Cavanaugh Mound, Brown Mound would also have been visible from much of the wide bottomlands between the sites.

Figure 22 shows the viewshed from the top of Skidgel Mound. Because it is already on a local topographic high, its overall viewshed is larger than that for both Brown and Cavanaugh mounds. Again, the largest portion 


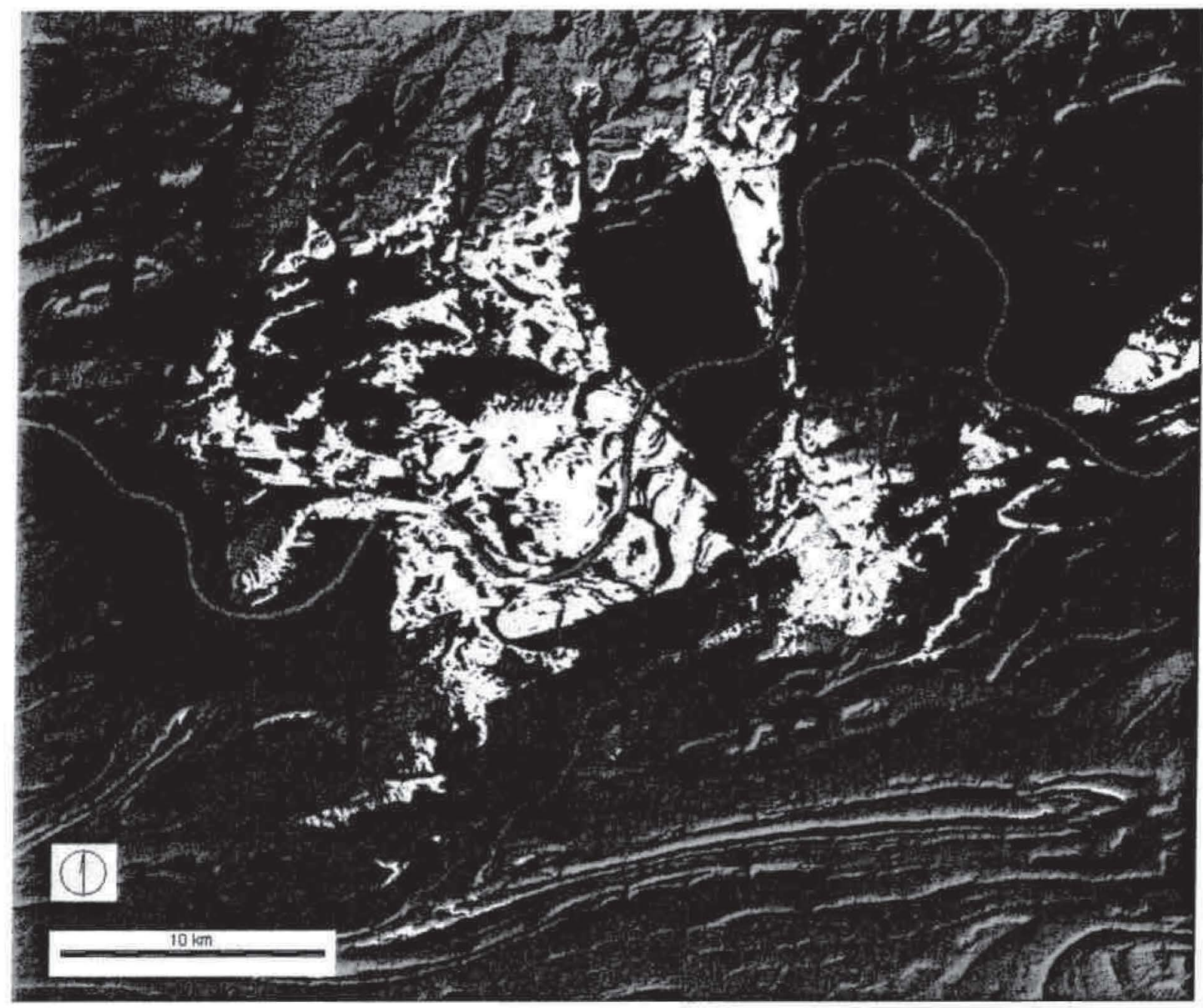

Figure 20. Viewshed from the top of Cavanaugh Mound. The Spiro and Skidgel sites are well within this view.

of the viewshed looks east over the Poteau/Arkansas River bottoms. Similar to the viewshed from Brown Mound, several of the hills back from the bluff line of the Arkansas River are within the viewshed, both to the south and to the north. The viewshed also encompasses much of the bottomlands west of Skidgel (the Redland Bottom). The high, steep northern bluff of the Arkansas River southwest of Skidgel blocks the view into the bottoms farther up river.

To travelers coming up the Arkansas River either on foot or by boat, the first mounds to come into sight would have been those at Spiro and Skidgel. Barring tall vegetation blocking either, they would have come into view at about the same time, just as the travelers came into the broad stretch of bottomlands a little east of what is now the Oklahoma/Arkansas state line. Although Skidgel would have been a little farther away, it is situated on a local prominence and may have come into view first. About halfway through the bottomlands (again barring any tall vegetation in the way) Cavanaugh Mound would have come into view, off to the left.

To travelers coming down the Arkansas River, Skidgel Mound would have been clearly visible as a mound on an already existing peak, right at the top of the steeply rising bluff line. This would have come into sight as the travelers entered the Redland Bottom. Cavanaugh Mound and mounds at Spiro would not have been visible until the travelers rounded the final bend into the Poteau/Arkansas River bottoms. From most locations 


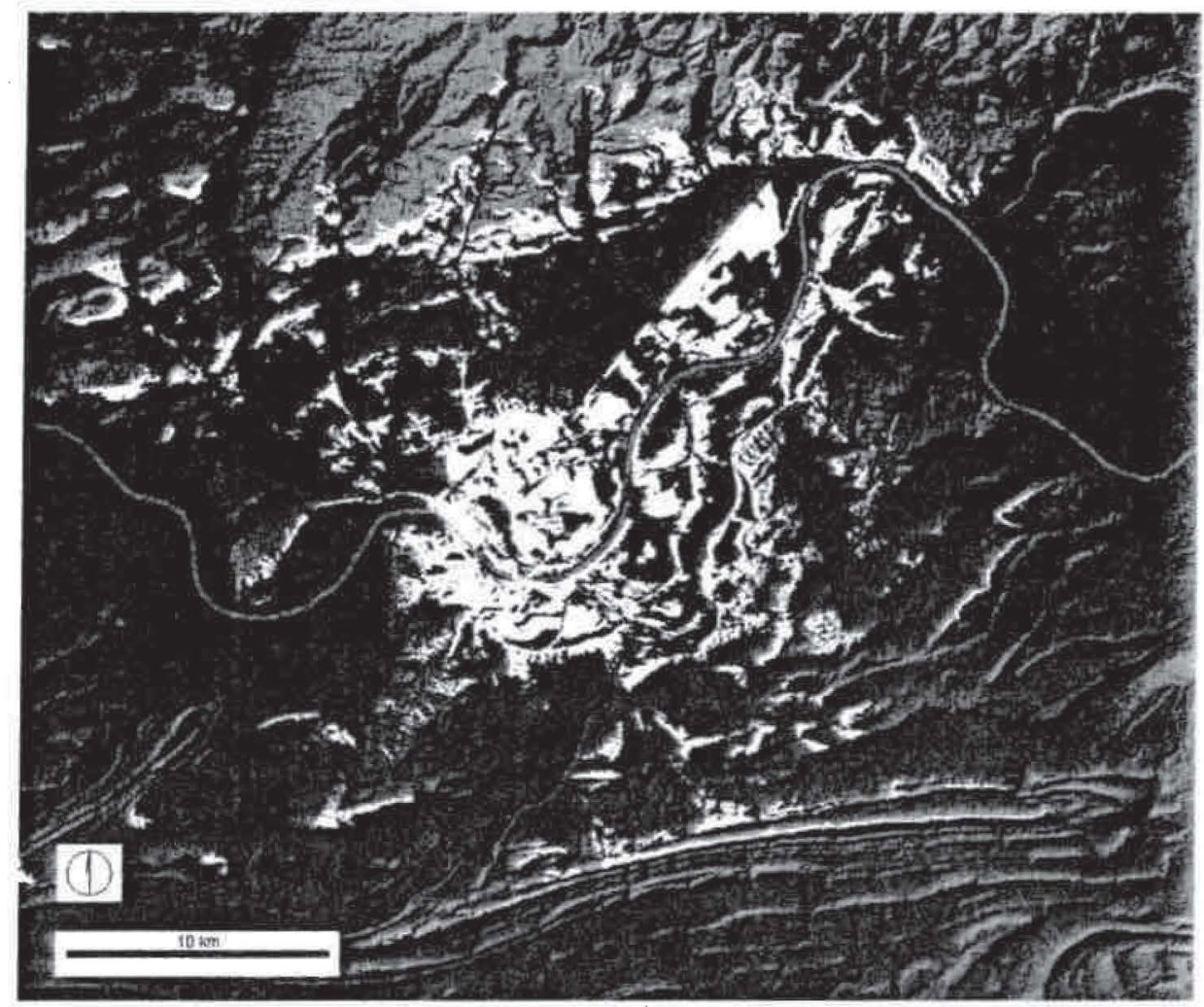

Figure 21. Viewshed from the top of Brown Mound at Spiro.

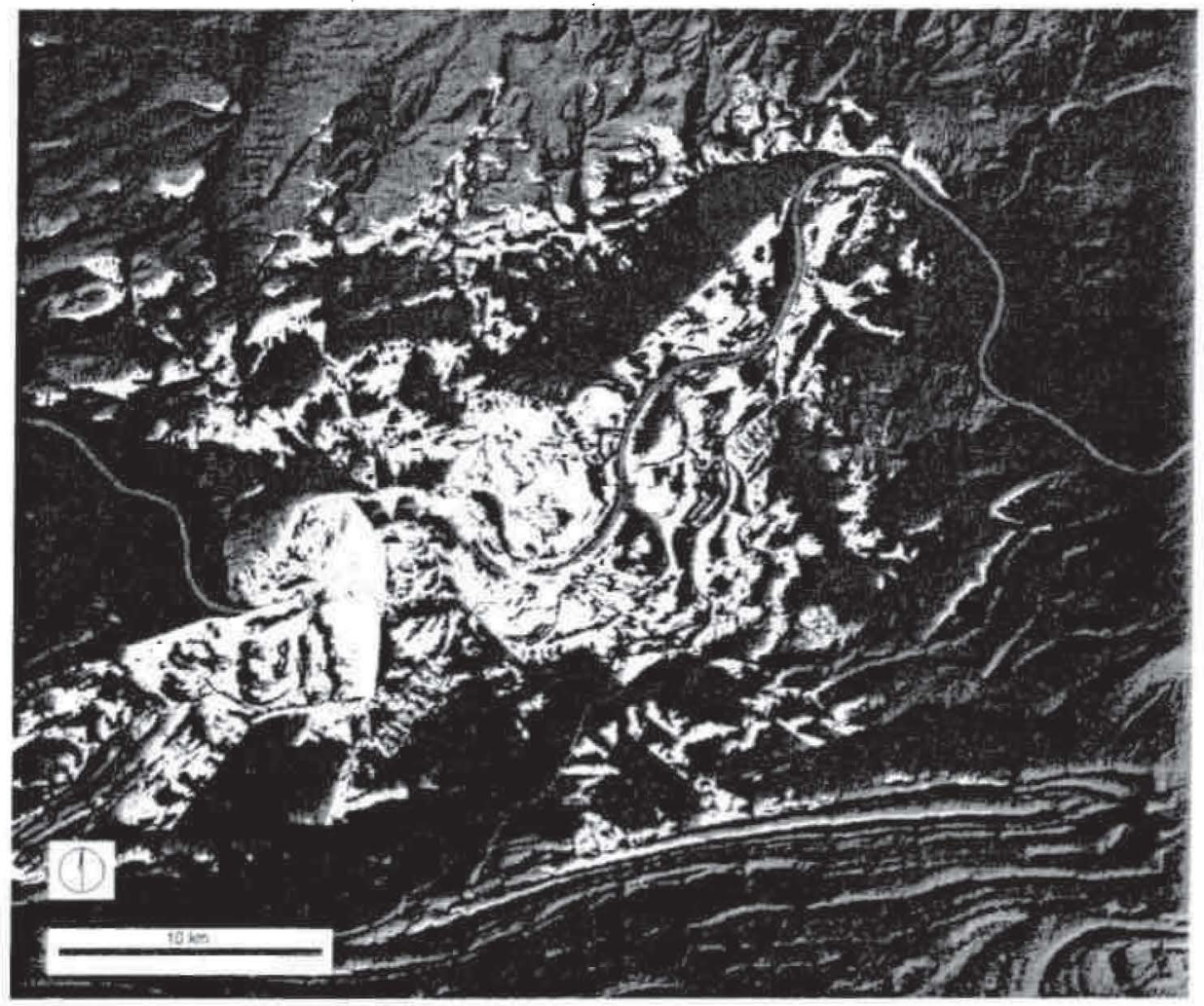

Figure 22. Viewshed from the top of Skidgel. Note that although Skidgel is on the western edge of a meander bend of the Arkansas River, the view from the mound is still primarily to the east, overlooking the Poteau/Arkansas River bottoms. 
within the Poteau/Arkansas River bottoms, a person would likely have been able to look up and see a mound at one or more of the sites.

\section{Mounds in the Arkansas River Valley}

Numerous Caddoan era mound sites are found along the Arkansas River and its tributaries. Spiro (34LF37), Norman (34WG2), and Harlan (34CK6) are the three largest and best known of these. Three primary mound types are recognized for this area, consisting of burial, structure, and platform mounds. Structure mounds are generally low, conical mounds erected on top of structures that appear to have been used as charnel houses or temporary burial locations. Burial mounds are conical, elongated, or multi-lobed features that are usually the result of numerous episodes of mound building. Grave goods are commonly associated with burials in these mounds.

Platform mounds are the largest earthen structures found in the Arkansas River valley. These are generally flat-topped or "truncated pyramids," built in multiple episodes. Platform mounds generally contain no artifacts or burials. Their internal structure can be quite complex, however, revealing numerous stages of mound construction. A typical sequence of platform mound construction begins with a "fill" stage of a few decimeters of soil, sometimes constructed of basket loads of highly contrasting matrix. Each fill layer was "active" for some time, with structures built on top and sometimes pits excavated into the fill and then backfilled. Fill layers were typically capped with a thin layer of burnt or compacted sediment, which was in turn covered by another fill layer, and so on. The actual internal structures of platform mounds are quite complex, however, so even this "typical" sequence is suggestive only. The similarities of area platform mounds that have been excavated lie in their complexity and expression of cyclical building more than in any particular sequence or progression of construction. This cyclical building pattern is clearly expressed at several platform mounds throughout the region (see Brown [1996:172-179] for a discussion of this patterning and platform mounds in general).

Sites that contain several mounds are termed civic ceremonial centers, and appear to have served as the location of important community ceremonies tied to regional political power. Brown et al. (1978) constructed a hierarchical typology of civic ceremonial centers which they termed first, second, and third echelon. Sites are considered first echelon if they contain at least one burial mound and an associated structure mound. Second echelon centers contain several structure mounds, at least one burial mound, and an additional platform mound. Third echelon centers are essentially large second echelon centers with the addition of a fourth mound type or other large architectural element. The additional mound type or architectural element is generally unique to the site, suggesting an "organizational discontinuity with the lower-order centers" (Brown et al. 1978:189). In the case of the Spiro site, the unique architectural element is the Craig mound with four conical burial mounds joined by earthen saddles.

Cavanaugh appears to be a typical platform mound for the region, except for its isolation from other mounds or from an associated residential area. Because it is a platform mound alone on the landscape, isolated from closely associated mounds, it does not fit into Brown et al.'s (1978) echelon system.

Figure 23 shows a shaded relief representation of Cavanaugh Mound compared to some other large Caddoan platform mounds in the region. The Craig Mound at Spiro is included as an aid in visualizing the scale of these earthworks; Craig has been reconstructed and undoubtedly numerous readers have visited the site and have a strong and personal impression of how large that structure is. For purposes of this comparison, Craig Mound was based on a topographic map of Spiro (Peterson 1989:2 and Figure 1); Brown Mound was based on the description by Orr (1946:230); Skidgel was based on the "primary" flat-topped mound (before a final layer converted the mound to a conical shape), from Brown (1996:177 and Figure 1-56); Harlan Unit 7 was based 
on a detailed topographic map (Bell 1972:186 and Figure 21); and the reconstruction of Cavanaugh was based on the 2004 mapping efforts described in this article.

These representations are not meant to be exact; the edges and heights of the mounds are difficult to reconstruct even for those that have been fully excavated. From the accumulated effects of centuries of erosion and natural soil forming processes, combined with decades of plowing, looting, and other historic disturbances, the mounds have likely been altered in ways we cannot reconstruct, and any determination of a mound's exact shape and size is only an approximation. Still, the general outlines and sizes may be compared within reasonable limits of uncertainty. By almost any measure, Cavanaugh is a large mound, and certainly ranks as one of the most impressive in the Arkansas River valley and adjacent regions.

\section{Conclusions and Further Questions}

Cavanaugh Mound is certainly an important archeological resource and a prominent mound in this region or anywhere within the American Southeast. It appears to be a complete platform mound, and had apparently been "used" for at least two cycles of construction. Unlike other platform mounds in the region, though, it is alone on the landscape and appears to not have an associated residential area. Its inter-visibility with the Spiro and Skidgel sites, and similarity of viewshed overlooking the Poteau/Arkansas River bottoms, is suggestive of a connection but this is not conclusive.

I have not addressed the question of dating in this article simply because no dates exist for Cavanaugh Mound. Dollar (1958) mentions a single pottery sherd reportedly found in the field around the mound, but he

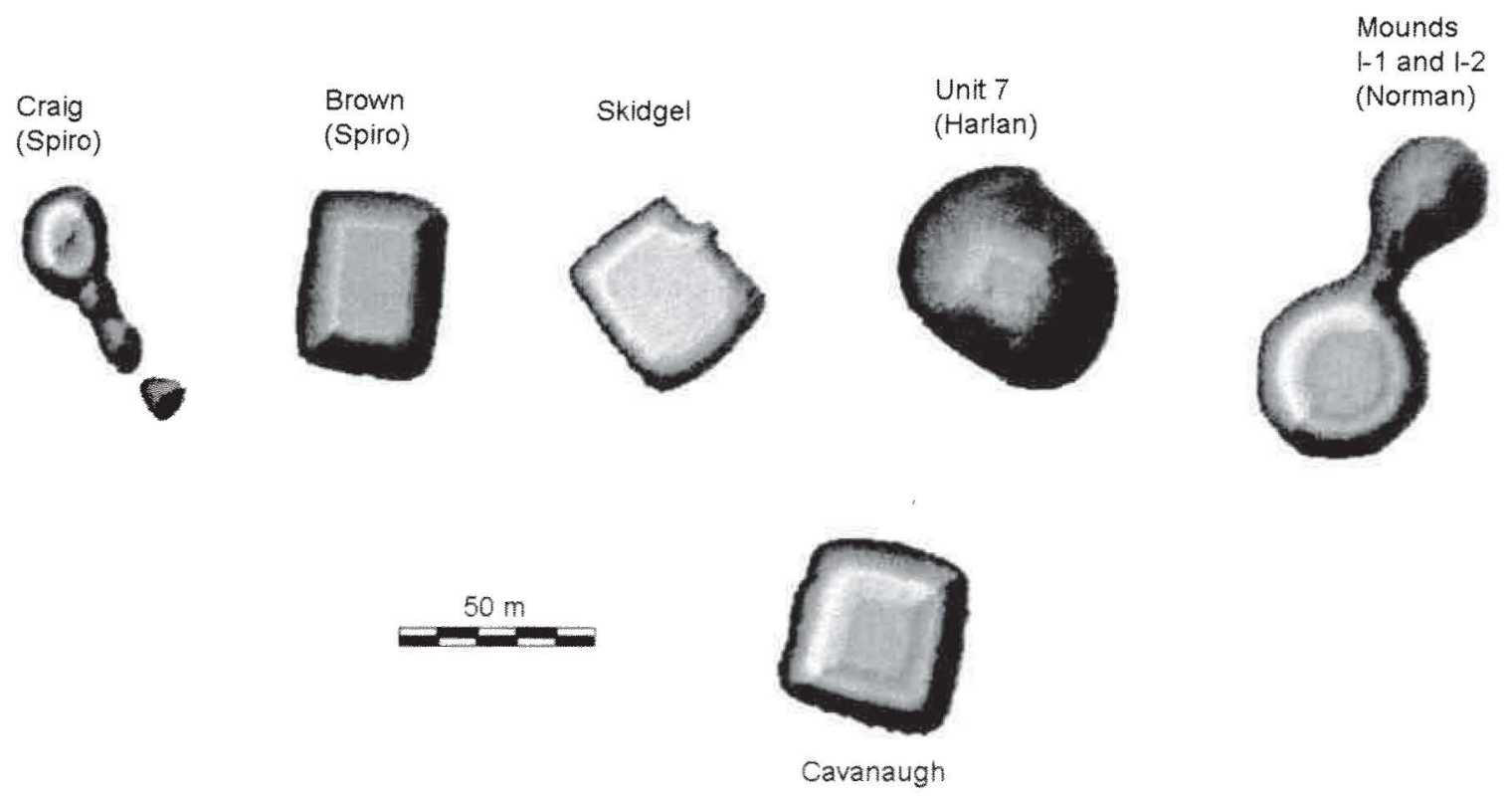

Figure 23. Shaded relief representations of several large mounds in the Arkansas River valley. 
includes no description of what it looked like, or whether it was even time-diagnostic. Orsbun noted seeing charcoal in the exposed profile during his 1991 visit to the site, but apparently took no samples. No datable material was noted during the 2004 investigations. The only way to date the mound at this point is to compare its size, shape, and internal structure to other area mounds. By these measures, it appears to be at least roughly contemporaneous with other Caddoan era platform mounds, but any more specific date would be speculation only. Unless datable material is recovered from within the mound itself, its timing will remain vague.

Similar to other platform mounds, Cavanaugh holds great potential for revealing various aspects of the social and ceremonial life of the people who constructed it. Rather than the typical discarded or displaced artifact debris so common in the archeological record, mounds are monumental artifacts in primary context, constructed for the purpose of ritual. Sears (1961:227) terms this type of structure "fossilized ceremony." Mounds are thus one step closer to the human condition we try to understand as archeologists: if we reconstruct the building techniques and sequences within and between mounds, we reconstruct something of the conceptual framework of the people who built them. We know so little about Cavanaugh Mound today that not much progress can be made along these lines, but because of its unique status as a solitary mound isolated from other structures or an associated settlement, and because it is so well preserved, Cavanaugh certainly holds promise along these lines in the future.

\section{Acknowledgments}

I would like to thank Frank and Lillian Etter for their continued interest in Arkansas archeology and in Cavanaugh Mound in particular. Recent recording at the site was possible through the hard work of Jerry Hilliard of the Arkansas Archeological Survey, and Michelle Berg Vogel and Bob Dalton, who graciously volunteered their time to help in field recording. I also thank the staff of the Arkansas Archeological Survey Office of the Registrar, the University of Arkansas Museum, and the University of Arkansas Libraries Special Collections.

\section{References Cited}

Bell, Robert E.

1972 The Harlan Site, Ck-6, a Prehistoric Mound Center in Cherokee County, Eastern Oklahoma. Memoir 2. Oklahoma Anthropological Society, Norman.

1980 Cavanaugh Mound Near Fort Smith. Oklahoma Anthropological Society Newsletter 28(2):11.

Brown, James A.

1996 The Spiro Ceremonial Center: The Archaeology of Arkansas Valley Caddoan Cultures in Easter Oklahoma. 2 Vols. Memoirs No. 29. Museum of Anthropology. University of Michigan, Ann Arbor.

Brown, James A., Robert E. Bell, and Don G. Wyckoff

1978 Caddoan Settlement Patterns in the Arkansas River Drainage. In Mississippian Settlement Patterns, edited by Bruce D. Smith, pp. 169-200. Academic Press, New York

Dollar, Clyde

1958 Report on Site Zeta [3SB3]. On fle at Arkansas Archeological Survey under 3SB3 site fles.

Finkelstein, I. Joe

1940 The Norman site excavations near Wagoner, Oklahoma. The Oklahoma Prehistorian 3:2-15.

Foote, E. B.

1903 Plat Book of Sebastian County, Arkansas. Imperial Publishing Co., Fort Smith, Arkansas. 
Goodspeed

1889 (1977) The Goodspeed Histories of Sebastian County, Arkansas. Reprinted from Goodspeed's History of Arkansas. Woodward \& Stinson Printing Co. Columbia, Tennessee.

Hayes, E. L.

1887 Atlas of Sebastian County, Arkansas. E.L. Hayes and Co. Chicago.

Heartfield, Price and Greene, Inc.

1984 Cultural Resources Survey of Proposed Ozark Gas Transmission Lateral Gas Gathering System, Annual Report No. 1. Report Prepared for Ozark Gas Pipeline Corp. and Delhi Gas Pipeline Corp., Dallas, Texas. Report on file, Arkansas Archeological Survey, Fayetteville.

Hilliard, Jerry

1981 An Archeological Survey of the Independent Living Community Fort Smith, Sebastian Co., Arkansas. Report on file, Arkansas Archeological Survey, Fayetteville.

Kay, Marvin, George Sabo III, and Ralph Merletti

1989 Late Prehistoric Settlement Patterning: A View from Three Caddoan Civic-Ceremonial Centers in Northwest Arkansas. In Contributions to Spiro Archeology: Mound Excavations and Regional Perspectives, edited by J. Daniel Rogers, Don G. Wyckoff, and Dennis A. Peterson, pp. 129-157. Studies in Oklahoma's Past No. 16. Oklahoma Archeological Survey, Norman.

McAlexander, William

1994 Hwy 253 Safety Improvements, Sebastian County. Archeological Report for Arkansas Highway and Transportation Department, on file, Arkansas Archeological Survey, Fayetteville.

Minor, Barbara

1995 Indian Mound. Journal of the Fort Smith Historical Society 19(1):16-17.

Nuttall, Thomas

1821 A Journal of Travels into the Arkansa Territory, During the Year 1819. With Occasional Observations of the Manners of the Aborigines. T. H. Palmer, Philadelphia.

Orr, Kenneth G.

1946 The Archaeological Situation at Spiro, Oklahoma: A Preliminary Report. American Antiquity 11:228-255.

Perttula, Timothy K.

1996 Caddoan Area Archaeology Since 1990. Journal of Archaeological Research 4(4): 295-348.

Peterson, Dennis A.

1989 The Excavations. In Contributions to Spiro Archeology: Mound Excavations and Regional Perspectives, edited by J. Daniel Rogers, Don G. Wyckoff, and Dennis A. Peterson, pp. 1-14. Studies in Oklahoma's Past No. 16. Oklahoma Archeological Survey, Norman.

Rogers, Hugh C.

1954 Indian Relics and Their Story, a Handbook for Collectors. Franklin Print Co., Fort Smith, Arkansas.

1956 Letter to Dr. Charles McGimsey, University of Arkansas. University of Arkansas Museum X-Files, Fayetteville, Arkansas.

Sabo, George III

1986 Preliminary Excavations at the Huntsville Site: A Caddoan Civic-Ceremonial Center in Northwest Arkansas. In Contributions to Ozark Prehistory, edited by George Sabo III, pp. 55-76. Research Series No. 27. Arkansas Archeological Survey, Fayetteville.

Sears, William $\mathrm{H}$.

1961 The Study of Social and Religious Systems in North American Archacology. Current Anthropology 2:223-246.

Shaeffer, James

1956 News - Salvage Archaeology. Oklahoma Anthropological Society Newsletter 5(11): 4.

Vogel, Gregory, Marvin Kay, and Louis Vogele, Jt.

2004 A Platform Mound at the Norman Site (34WG2), Eastern Oklahoma. Southeastem Archaeology, in press. 